\title{
CCAF-DB: the Caribbean and Central American active fault database
}

\author{
Richard Styron, Julio García-Pelaez, and Marco Pagani \\ Global Earthquake Model Foundation, Via Adolfo Ferrata 1, Pavia 27100, Italy \\ Correspondence: Richard Styron (richard.styron@globalquakemodel.org)
}

Received: 22 February 2019 - Discussion started: 25 March 2019

Revised: 23 January 2020 - Accepted: 10 February 2020 - Published: 25 March 2020

\begin{abstract}
A database of $\sim 250$ active fault traces in the Caribbean and Central American regions has been assembled to characterize the seismic hazard and tectonics of the area, as part of the Global Earthquake Model (GEM) Foundation's Caribbean and Central American Risk Assessment (CCARA) project. The dataset is available in many vector GIS formats and contains fault trace locations as well as attributes describing fault geometry and kinematics, slip rates, data quality and uncertainty, and other metadata as available. The database is public and open source (available at: https://github.com/GEMScienceTools/central_am_carib_ faults, last access: 23 March 2020), will be updated progressively as new data become available, and is open to community contribution. The active fault data show deformation in the region to be centered around the margins of the Caribbean plate. Northern Central America has sinistral and reverse faults north of the sinistral Motagua-Polochic fault zone, which accommodates sinistral Caribbean-North American relative motion. The Central Highlands in Central America extend east-west along a broad array of normal faults, bound by the Motagua-Polochic fault zone in the north and trench-parallel dextral faulting in the southwest between the Caribbean plate and the Central American forearc. Faulting in southern Central America is complicated, with trenchparallel reverse and sinistral faults. The northern CaribbeanNorth American plate boundary is sinistral off the shore of Central America, with transpressive stepovers through Jamaica, southern Cuba and Hispaniola. Farther east, deformation becomes more contractional closer to the Lesser Antilles subduction zone, with minor extension and sinistral shear throughout the upper plate, accommodating oblique convergence of the Caribbean and North American plates.
\end{abstract}

\section{Introduction}

The Caribbean and Central American region is characterized tectonically by deformation zones surrounding plate boundaries with rapid relative plate motion. While this is not an uncommon situation on Earth, it is troublesome from a seismic risk perspective because nearly all of the Caribbean plate's subaerial land is within these deformation zones. As a result, most of the region's 100 million inhabitants are within $\sim 50 \mathrm{~km}$ of at least one active fault.

Though earthquakes in the region have been described throughout history and the area has received a fair amount of scientific study, there has so far been little coordinated and internally consistent assessment of seismic sources and hazard covering the entire Caribbean and Central American region. To this end, the GEM Foundation and its collaborators are working on the USAID-funded Caribbean and Central American Risk Assessment (CCARA) project (https: //ccara.openquake.org/, last access: 23 March 2020) to calculate probabilistic seismic hazard and risk analysis for the region. As a component of the CCARA project, we have compiled a database of active faults (Styron et al., 2018, available at: https://github.com/GEMScienceTools/central_ am_carib_faults, last access: 23 March 2020), which is used to create fault sources for probabilistic seismic hazard analysis (PSHA).

This paper describes the format of the database and the methods used to construct it (i.e., mapping the faults in GIS) as well as the data contained therein. The database description is contained in the eponymous section. The data are described in the "Overview of regional faulting" section, which documents the structures at the minimum level of detail required for constructing a seismic hazard source model with an understanding of the sources of the data and attributes as 
well as their uncertainties. This section also serves readers more interested in tectonics than quantitative hazard analysis as an introduction to the patterns of active faulting and literature of any given region. This section is not meant to be read as a start-to-finish narrative but instead as a reference for each region. Finally, the paper discusses where the most important fault research should be done from a seismic hazard and risk perspective in the "Faulting, seismic risk and uncertainty" section.

Seismic hazard and risk analysis is multidisciplinary, involving scientists and engineers working on field geology, geodesy, seismology, structural and civil engineering, economics, finance, and policy. Consequently, the analysis process consumes data generated by one field and produces data (or models) intended for another field. The CCAF-DB and this paper, which documents it, serve to synthesize fault geologic and geodetic information for seismic hazard workers who may not be experts in those fields. Consequently, many of the typical concerns of tectonicists are not considered in detail here. Research into geodynamical topics such as the driving forces of deformation, or geological topics such as the longer-term history of faulting and the evolution of the Caribbean plate, which have motivated much of the data collection in the region, is important but not our focus.

A note on terminology: consistent with usage in quantitative fields spanning science, engineering, finance and governance, hazard describes the likelihood and occurrence of potentially damaging events, while risk describes the likelihood of loss to human life and assets given the hazard. In the case of seismic hazard and risk, a seismic hazard model is a probabilistic model of earthquake occurrence and consequent ground motion over a region, while a seismic risk model convolves probabilistic ground motion maps with an exposure model incorporating population and infrastructure maps with quantitative assessment of the response of assets to different levels of ground shaking.

\section{Database description}

The Caribbean and Central American Active Fault Database is a GIS-based database of $\sim 250$ fault traces from the Chiapas region of Mexico south to Panama and east through the Greater and Lesser Antilles (Fig. 1). The dataset is meant to complement similar datasets with coverage of northern South America: the Active Tectonics of the Andes dataset (Veloza et al., 2012) and the SARA Active Faults database (Alvarado et al., 2017) and central Mexico (Villegas et al., 2017). Therefore, faults in central Mexico and northern South America (including the Caribbean-South American plate boundary) have not been included in this database.

\subsection{Purpose}

Fault databases such as the CCAF-DB may serve a variety of purposes, ranging from seismic hazard analysis to earthquake and tectonics research and education and general interest. This list describes our priorities for the database in order of decreasing importance and guides how and when we map faults and assign attribute values, particularly under ambiguity or ignorance of these characteristics.

The GEM CCAF-DB and the enveloping Global Active Faults Database (Styron and Pagani, 2019) are also made with a philosophy and technological approach more similar to open-source software than many previous fault datasets. The database itself is open source, under a Creative Commons Attribution License (CC-BY 4.0), and is developed in an iterative way that encourages user and community contribution and feedback. As the database is hosted on GitHub (https://github.com/GEMScienceTools/central_am_ carib_faults, last access: 23 March 2020), this is most readily done through the capabilities provided there (such as "issues" and "pull requests"), but data, comments and suggestions emailed to the authors are also highly encouraged.

Regardless of the precise mechanisms of community participation, we view the database as constantly evolving, made with the intention of having the most up-to-date data readily available rather than having infrequent major releases where most or all of the regions are remapped or otherwise updated.

All faults should be considered interpretations of structures as described in the literature as well as structures expressed in topographic, seismological, geodetic and remotesensing data (i.e., "base datasets") and not an attempt at representing any structure exactly as given by a listed reference for the structure. The reasoning behind this is grounded in our objective of providing regional fault coverage primarily for fault-based PSHA and the consequent desire for continuity or consistency with similar expressions of faulting in the base datasets or other studies. Similarly, many structures are drawn inconsistently from publication to publication, or at a scale and resolution unsuitable for our reproduction, and given the scope of our work it is not always desirable or practical to choose a single representation from a suite of competing maps. Researchers with particular suggestions, criticisms or grievances are highly encouraged to communicate this to us through their preferred channels.

Furthermore, due to the dynamic and evolving nature of the database, we encourage users to check regularly for updates, particularly users that are performing quantitative or other intensive analysis; for those with more casual purposes, this may not be necessary.

The probability of major changes to the database in the foreseeable future is highest before 2020: in 2019, GEM released the first version of the GEM Global Active Fault Database (Styron and Pagani, 2019, https://github. com/GEMScienceTools/gem-global-active-faults, last access: 23 March 2020), which will be a harmonized collection 


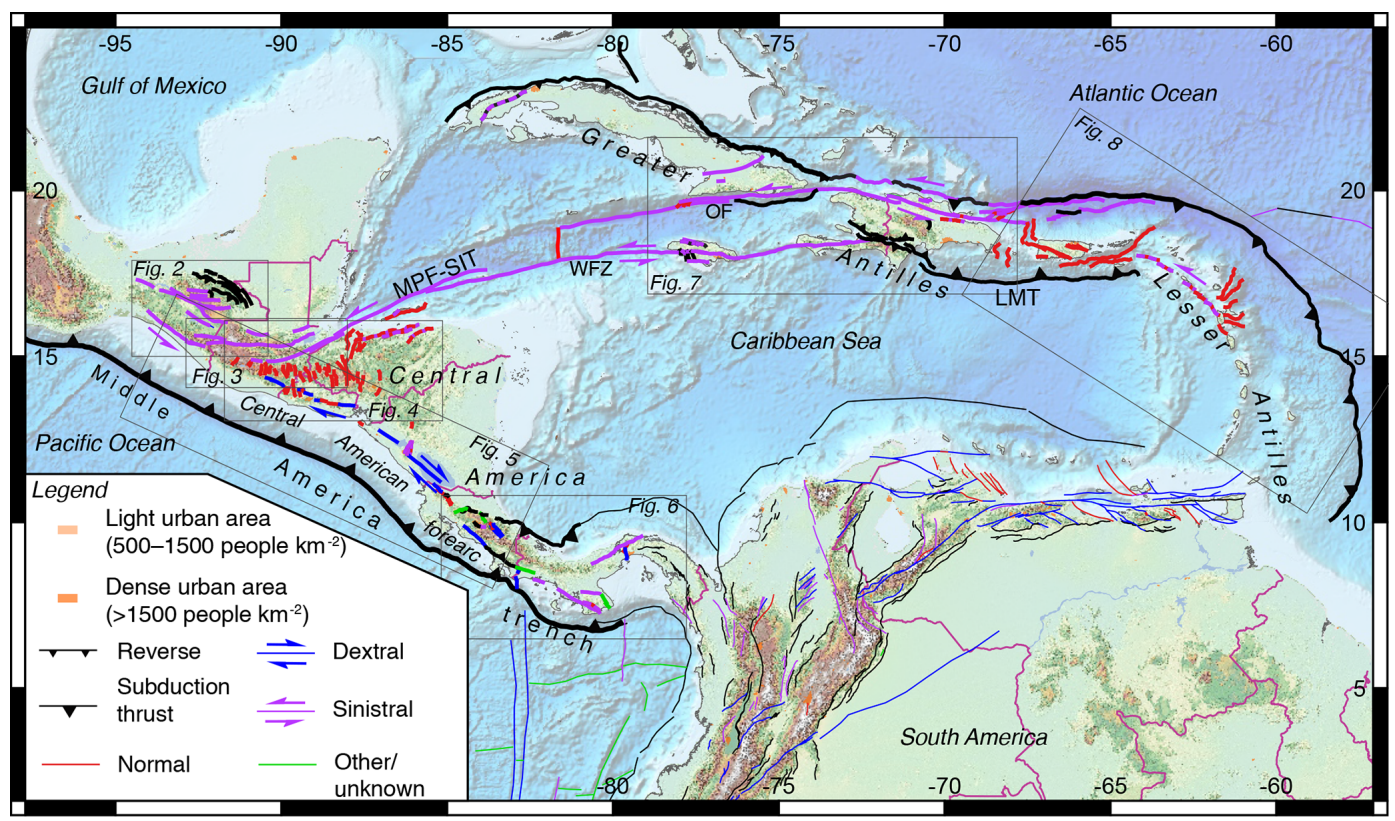

Figure 1. Active faults of the Caribbean and Central America. Faults with thicker lines are in the CCAF-DB, while faults with thinner lines in South America are from the SARA (https://sara.openquake.org/, last access: 23 March 2020) and ATA (Veloza et al., 2012) datasets. LMT is the Los Muertos trough. MPF-SIT is the Motagua-Polochic fault and Swan Islands transform fault. OF is the Oriente fault. WFZ is the Walton fault zone. Names given in italicized text are geographic features, while those in regular text are structural features. Population data are from (C) WorldPop (Sorichetta et al., 2015). Base topography is from the Shuttle Radar Topographic Mission (Farr et al., 2007) (in the public domain), and coastlines are from Wessel and Smith (1996), based on public-domain data.

of existing and new active fault datasets covering all of the deforming world. The CCAF-DB is the first fault database developed in-house and serves to some degree as a testing ground for the final database structure. While we do not anticipate major changes to the faults included in the database, the possibility does exist for breaking changes to the database schema, for example column names or formatting, that will aid in the assembly or application of the global database. Any such changes will be well documented within the data repository.

\subsection{Mapping methods}

Faults were mapped in QGIS, a free and open-source GIS application, based on existing mapping as well as the base datasets. All structures were mapped on Shuttle Radar Topography Mission (SRTM) digital elevation data (Rosen et al., 2000) at 30,90 or $250 \mathrm{~m}$ resolution depending on the geometric complexity of the faults as well as on their relative importance in characterizing the tectonics, hazard and risk of the region.

As is common with digital mapping, there is large variation in the effective map scale an individual structure is mapped at, but map scales generally range from $1: 12000$ to $1: 150000$ for onshore faults. This depends on the size, complexity and importance of a given structure or set of structures as well as the resolution of imagery in Google
Earth and other datasets that aid in fault characterization. However, faults illustrated in the literature are displayed at a scale of $1: 100000$ to $1: 5000000$ (regardless of the scale of the original mapping), with more detail reserved for small study regions (i.e., trench sites) that typically do not show the full extent of the fault and its potential linkage with nearby faults. Plates or regional maps not published in journals may show a greater expanse on a smaller scale (e.g., $1: 50000$ ) but are rarely easily available electronically and may not distinguish active faults from older structures. The difference in map scale between our traces and the maps in the literature is a primary reason why we consider our fault traces to be interpretations of both the literature and the base datasets.

A major concern in this mapping is fault segmentation. Identifying the active strands in anastomosing fault zones with many subfaults can be challenging. Consistent with our first objective of hazard analysis, we map fault segments with the intention of representing the likely start and end points for a full-length, single-segment rupture. This is dominantly based on geometric criteria such as bends and stepovers (e.g., Wesnousky, 2008), but in a few cases fault slip rates or inferred dips change enough along strike that smooth and continuous fault traces are broken up into segments. The foremost example of this is the northern Caribbean megathrust and its splay into Cuba, which progressively changes the rake and slip rate along strike though there is without a doubt a single continuous fault plane at depth. In general, faults be- 
low $10 \mathrm{~km}$ in length are not included individually; these may be segments of an anastomosing system and then are therefore mapped continuously if possible, or if they are more isolated they are not included unless they are of special significance (i.e., very prominent in the landscape or close to a major city).

Offshore faults are mapped on bathymetry from the Marine Geoscience Data Clearinghouse's Global MultiResolution Topography Synthesis data (Ryan et al., 2009). Bathymetry resolution is variable but in general is quite poor. Therefore the accuracy, resolution and veracity of offshore faults are lower than for subaerial faults, and fault cata$\log$ completeness is surely worse as well. Nonetheless these structures remain important sources of seismic and tsunami hazard and are worthy of more study in the future.

\subsubsection{Assessment of fault activity}

The activity of faults is assessed through evaluation of published fault-specific studies; local to regional seismicity; and geodetic strain consistent with the inferred fault kinematics, geomorphic evidence for late Quaternary activity, and the relationship between a structure and those nearby with known activity status. While the former criteria are self-explanatory, the latter criteria merit exposition.

Geomorphic criteria suggestive of neotectonic fault activity include obvious fault scarps offsetting Quaternary deposits in the direction of fault motion, systematic deflection of streams crossing the fault trace, signs of subsidence and active sedimentation on the downthrown block of a dipslip fault (indicated more strongly by the presence of an internally drained basin), a sharp and well-defined range front with triangular facets (particularly for normal faults), and growing folds and domes emerging from the basin near reverse-faulting range fronts that may be fault propagation folds above young blind thrusts at the toe of a thrust wedge. Similarly, a lack of these diagnostic features suggests fault inactivity. More explicitly, clearly undeformed Quaternary deposits overlying obviously faulted bedrock, and erosion and external drainage of sediments capping downthrown blocks, more strongly suggest that a pre-Quaternary fault has had little to no late Quaternary movement regardless of bedrock evidence of slip. However, given the tropical climate and intense rainfall of Central America and the Caribbean, evidence for activity based on seismic and geodetic data is weighted more heavily than geomorphic evidence for inactivity, as neotectonic feature preservation and identification are both more difficult here than in colder, drier and lessvegetated areas.

If a fault displays strong evidence of either activity or inactivity, this evidence may aid in evaluating the activity status of neighboring faults. The particulars of this are based on the geometry of faulting and the patterns of deformation. Strain in thrust belts is commonly localized at the frontal thrust (insequence thrusting), whereas faults farther back in the wedge may be well expressed in the bedrock but no longer active. Therefore, thrusts along strike of a known active thrust are more likely to be active, while those behind it are less likely; evidence for active slip on out-of-sequence thrusts needs to be more convincing than for frontal thrusts, particularly if the frontal thrusts are active. These same considerations apply with strike-slip faults, as slip is usually localized on a major fault and transferred along strike to the next segment rather than to a parallel strand. However, the situation is different with normal faulting. Arrays of active, parallel normal faults are quite common globally, yielding basin and range physiography as in the highlands of Honduras and Guatemala, though slip rates and activity may change along strike.

The criteria for including a fault in the database is a blend of the evidence for late Quaternary faulting and the local importance of a given structure, though we are biased towards inclusiveness. Because active fault traces are more concentrated in regions of high strain and rapid strain rate, a major fault system such as the Motagua-Polochic fault system (Fig. 1) will have some small strands that may have relatively low strain rates and neither contribute much to the overall seismic hazard of their vicinity nor lend much insight into local or regional tectonics. Identifying and characterizing each of these structures is time-consuming and does not contribute much to our major objectives, so these faults may not be included. However, a similar fault in a very slowly deforming region far from a plate boundary may be the most important structure for many kilometers and therefore merits inclusion. Nonetheless, we recognize that for some purposes (such as statistical analysis of fault networks), the consistency of fault representation is quite important, and with further iteration we expect to increase the homogeneity of fault catalog completeness between areas.

\subsection{Assignment of attributes}

The database has a fairly minimal set of attributes that are necessary for seismic hazard analysis as well as a few ancillary fields (Table 1). These provide information on the fault geometry, kinematics, slip rate, uncertainties, references, date of last earthquake and a field for any notes worth including.

Fault attributes may be text, integers or floatingpoint numbers which represent continuous random variables $^{1}$, depending on the attribute. Integers are used in a semi-quantitative or categorical sense and do not represent continuous random variables; for instance, the

\footnotetext{
${ }^{1}$ A continuous random variable is a random variable (i.e., a variable that may take more than one value or with an unknown value) that may take any value on the number line between minimum and maximum bounds. These bounds may be finite, as in the case of a fault scarp between 2 and $3 \mathrm{~m}$ tall, or they may be infinite, as in the case of the normal distribution. In contrast, a discrete random variable may take one of a set of non-continuous values; a six-sided die is the canonical example.
} 
Table 1. Attributes for active structures. dip and rake are in degrees; strike_slip_rate,dip_slip_rate, vert_sep_rate, shortening_rate and net_slip_rate are in millimeters per annum; and other variables are categorical and unitless.

\begin{tabular}{llll}
\hline Attribute & $\begin{array}{l}\text { Data } \\
\text { type }\end{array}$ & Description & Example \\
\hline dip & Tuple & Dip & $(40,30,50)$ \\
dip_dir & String & Dip direction & W \\
downthrown_side_id & String & Direction of downthrown side & NE \\
average_rake & Tuple & Slip rake of fault & $(45,25,55)$ \\
slip_type & String & Kinematic type & Sinistral \\
strike_slip_rate & Tuple & Strike slip rate on fault & $(1.5,0.5,2.5)$ \\
dip_slip_rate & Tuple & Dip slip rate & $(1.5,0.5,2.5)$ \\
vert_sep_rate & Tuple & Vertical separation rate & $(1.5,0.5,2.5)$ \\
shortening_rate & Tuple & Horizontal shortening rate & $(1.5,0.5,2.5)$ \\
net_slip_rate & Tuple & Total slip rate on fault & $(1.5,0.5,2.5)$ \\
activity_confidence & Integer & Certainty of neotectonic activity & 1 \\
exposure_quality & Integer & How well exposed (visible) fault is & 2 \\
epistemic_quality & Integer & Certainty that fault exists here & 1 \\
last_movement & String & Date of last earthquake & 1865 \\
name & String & Name of fault or segment & Polochic \\
fs_name & String & Name of fault system & Motagua-Polochic \\
reference & String & Paper used & Rogers and Mann $(2007)$ \\
notes & String & Any relevant notes & May be creeping \\
\hline
\end{tabular}

activity_confidence attribute carries a value of 1 (if activity is certain) or 2 (if activity is uncertain), and the accuracy attribute lists the denominator of the scale at which a structure is mapped (such as 50000 for $1: 50000$-scale mapping). Attributes that represent random variables are given by a 3 -tuple ${ }^{2}$ of numbers in a (most likely, minimum, maximum) format (e.g., $(135,90,180))$. This tuple is intended to represent a triangular probability distribution, with the most likely value being the mode and the minimum and maximum values being the bounds of the probability distribution rather than 1 SD (standard deviation) confidence intervals or quantiles. However, there may be instances when these values are taken from the literature and Gaussian parameters (mean, standard deviation) are listed, either due to ambiguity in the source or by mistake during data entry. Users performing quantitative analysis with the numbers given are strongly encouraged to check the listed references for each relevant structure. Note that for convenience and clarity in data entry and interpretation, if no appreciable uncertainty is included, the tuple may simply be written as (most likely) ", as in $(90.0$,$) .$

\footnotetext{
${ }^{2} \mathrm{~A}$ tuple is a fundamental term in mathematics and computer programming and is simply a finite, ordered list or sequence of items. An $(x, y)$ coordinate pair, the instructions (lather, rinse, repeat) and a list of the months (April, May, June) are all examples of tuples.
}

\subsubsection{Fault geometry and kinematics}

Attributes relating to fault geometry and kinematics (dip, dip_dir, downthrown_side_dir, average_rake, slip_type) are taken from the literature where available and inferred elsewhere, as described below. The dip and average_rake parameters are tuples; rake is in the Aki and Richards convention (Aki and Richards, 1980). The slip_type, dip_dir and downthrown_side_dir attributes are categorical. slip_type gives the name of the kinematic type of the structure (e.g., Reverse or Dextral-Normal). In the case of an oblique-slip category, the first word is assumed to be dominant; i.e., a Dextral-Normal fault is more dextral than normal. dip_dir is the cardinal direction that a fault dips in, and downthrown_side_dir is the cardinal direction of the downthrown block.

Fault kinematics are interpreted from the literature and from the base datasets. Fault kinematics in the region are far less ambiguous than in many others because the epistemic certainty resulting from the high strain rate (producing an abundance of earthquake focal mechanisms and a geodetic velocity field with a high signal-to-noise ratio) and generally young rocks (which do not show the scars of many previous orogenies) far outweigh the effects of tropical erosion, which does not always preserve obvious offset geomorphic markers. Aside from a few enigmatic structures such as the Tonalá shear zone in southern Mexico (e.g., Authemayou et al., 2011; Molina-Garza et al., 2015), the kinematic uncertainty that exists is usually whether individual faults in a transpressional or transtensional region each have oblique 
slip or whether the zones are slip partitioned (such as the faults in the Managua graben, Nicaragua). In questionable regions, we evaluate the kinematic obliquity of a given structure based on how oblique the local focal mechanisms are and whether there is a visible distinction between strike-slip and dip-slip faults. A very small number of faults, particularly in Costa Rica and Panama, are not assigned fault kinematics because of very ambiguous geomorphology and strain fields. (The specifics of these problematic structures will be discussed in their respective sections below.)

Fault dip is similarly interpreted where not given in the literature. Strike-slip faults are given dips of $90^{\circ}$ where there is no evidence for dip slip. Normal faults are given mostlikely dips of $\sim 50-60^{\circ}$, unless geomorphic evidence indicates lower dip (i.e., clear, more shallowly dipping triangular facets). Normal faults thought to have relatively high displacements (i.e., more than a few kilometers) may be given slightly shallower dips to account for back rotation of the footwall (e.g., Buck, 1988). Uncertainties are evaluated on a case-by-case basis but are typically $10-15^{\circ}$ on either side of the most-likely value. Reverse faults are given dips of $\sim 20$ $30^{\circ}$ if they are relatively isolated but given more shallow dips if they appear to be basal decollement of a thrust wedge (e.g., Boyer and Elliott, 1982). Oblique-slip faults are given dips that are in between the "pure" slip endmembers.

\subsubsection{Slip rate}

Slip rates are generally taken from the literature, although in some instances they may be inferred based on those of well-studied faults in the same system. We include four slip rate components to account for the variation in measurable deformation using different techniques: net_slip_rate is the total slip rate on the fault plane, strike_slip_rate is the strike-slip component, vert_slip_rate is the vertical (not dip-slip) component and shortening_rate is the horizontal component perpendicular to the fault. The first three components are absolute values, but shortening_rate may take negative values to indicate extension across the fault. Values are given in millimeters per annum. All of these slip rate attributes are continuous random variables with the 3-tuple format described above.

Slip rates are unknown for the majority of the structures in the database and remain unassigned, though fortunately these are generally known for the major structures such as plate boundary faults.

\subsubsection{Additional attributes}

The remaining attributes are metadata that characterize the state of knowledge of the structure as well as ancillary information that may be useful for hazard modeling or other investigation.
The uncertainty of the structure (beyond what is included in the tuples described above) is given by four attributes, all of which are integers. accuracy describes the denominator of the scale the structure is mapped at. The next three attributes describe how certain we are about an individual structure. The values for each are integers and can be 1 (indicating high confidence) or 2 (indicating low confidence). activity_confidence describes the certainty that the structure is active (i.e., accumulating shear stress or is otherwise considered to have seismogenic potential). This is determined using the criteria given in Sect. 2.2 above. exposure_quality indicates how obvious the structure is in topographic and satellite imagery of the region. epistemic_quality describes the certainty that a fault is actually located where the trace is.

These latter three attributes are somewhat interrelated but are not the same. For example, a fault may have high epistemic_quality but poor exposure_quality if it is located in a well-defined valley that it has created and has produced seismicity in the instrumental record but lies buried underneath an active river channel and is not observable at the surface (the Septentrional fault in northern Haiti, e.g., Mann et al., 1998; Prentice et al., 2003, is a good example of this). Conversely, a fault may have high exposure_quality but poor epistemic_quality if it lies in a region with diffuse seismicity and clear photographic and geomorphic evidence for distributed or anastomosing faulting, but it is not obvious which trace best represents the active structure. (This last problem is less common in the present study area than in polydeformed desert regions that preserve expressions of faulting for tens or hundreds of millions of years.)

The $f z \_n a m e$ lists the name of the fault zone or fault system an individual fault segment may be a part of.

The last_movement attribute gives the calendar year of the last known major earthquake on a structure. This attribute is very incomplete in the database, both because it is simply unknown for so many structures and because relatively little effort was made to collect information on it during the database construction phase, as it is not used in standard, time-independent PSHA. Nonetheless it is of interest to many, so we have made a space for it.

The reference attribute lists one or more references for a structure. It is very important to note that (as described above) all structures here should be considered interpretations of both the literature and the base datasets, and the reference listed for any structure should not be taken as the sole source for the information that we have used for the structure; it is better to consider the listed reference to be a starting point that an interested user can go to for more information. A related point is that no listed reference should be considered responsible for any errors shown in the location or attributes of any structure in the database. Structures with "DEM" listed as the reference are taken mostly from topographic expressions of faulting rather than from the litera- 
ture; similarly structures with no reference at all given are taken from synthesis of all of the base datasets.

The notes attribute is simply a place to list any additional information that may be of use to users, particularly those interested in PSHA. Example information could describe down-dip changes in fault geometry, potentially associated historical seismicity, or caveats to the information or interpretations given for that structure.

\subsection{Data format}

The CCAF-DB is a GIS-based product and is given in several GIS-type vector formats. The dataset is mapped in a plain-text, human-readable GeoJSON format (primarily to track development with the git version control system) and is converted into additional file formats (GeoPackage, ESRI Shapefile, GMT, Google Earth KML) either directly in QGIS or through a script using the OGR2OGR utility.

As such, the GeoJSON (.geo json) format is the version of record. Some information (metadata) loss is possible when converting to any format other than GeoPackage, as other formats are limited in their ability to store all information. For example, the shapefile format cannot handle attribute names beyond a certain number of characters, so they may be truncated. GIS users are encouraged to use the GeoJSON format preferentially, as it is the most widely supported. GMT and Google Earth users will likely find the native formats for each to be the most practical.

\subsubsection{Version control}

The CCAF-DB is managed using the git version control software. This allows us to track and revert changes made to the data over time, to gracefully evaluate and merge contributions from other scientists, and to distribute the most upto-date version of the software at all times. Because git is designed around text changes, the text-based versions of the data (i.e., the GeoJSON, GMT and KML formats) will track feature-by-feature changes, while the binary formats (e.g., ESRI Shapefile and GeoPackage) are replaced with every committed change.

\subsection{Use of fault data in PSHA}

The CCAF-DB is intended to be used for seismic hazard analysis in the region and is used by GEM for this purpose in the CCARA project. However, the creation of a fault source characterization for a PSHA model requires more information than is released in this database and which we do not wish to release with the database. These are primarily characteristics of faults which are not direct observables, either in principle or in the practice of this data compilation; therefore these are effectively modeling decisions to be made by those performing the hazard analysis. For example, the maximum magnitude and magnitude-frequency distribution for each fault may not be directly observed. The upper and lower seismogenic depths are also very hard to constrain, especially in a compilation such as this, and the few constraints from geodesy are often subject to great uncertainty. Similarly, when information on a fault's slip rate is not available, this quantity must be estimated in the absence of strong data constraints or the fault must be left out of the PSHA model. Because we do not wish to make these decisions for others, and we do not wish to risk the confusion of our estimates for data, we are not including this information in the public database.

\section{Overview of regional faulting}

Here, we give an overview of the active structures throughout Central America and the Caribbean. This overview presents the data compiled in the CCAF-DB, with an emphasis on fault slip rates and other information relevant to seismic hazard assessment. Additionally, major uncertainties or conflicting interpretations of fault configurations or rates in the literature are discussed along with our chosen fault representations in these instances.

This section is primarily intended to be a guide to the data in each region for seismic hazard analysts, so they may understand the sources of the data and where uncertainties or data gaps may be important. We hope this section will also be of use to tectonics researchers or others who are interested in an up-to-date regional overview; however, many of the typical research interests such as the driving forces of deformation and the evolution of plates and faults through time are not discussed, as they are irrelevant to seismic hazard work.

We do not intend this section to be a comprehensive review of the tectonics or history of the region, and in our citations we favor newer papers over older sources, as these in general contain the highest-quality slip rate data (particularly geodetic data) and the most legible maps; these references also typically contain more thorough and scholarly discussions of the older literature than we have space for here.

The subsections in this section are ordered from north to south along the western margin of the Caribbean plate and then west to east along the northern and eastern margins of the Caribbean plate. Each subsection below describes a particular region and has an associated map (figure) that displays all of the structures in the region; for readability, the figure will not be referred to repeatedly in the text.

\subsection{Central America}

Active faulting and seismicity is ubiquitous throughout Central America. In southern Mexico, transpressional deformation occurs in the Chiapas fold and thrust belt and vicinity. The relatively slow and distributed deformation here transitions southward into more rapid and localized sinistral slip along the Motagua-Polochic fault zone in Guatemala, which is the main Caribbean-North American plate boundary struc- 


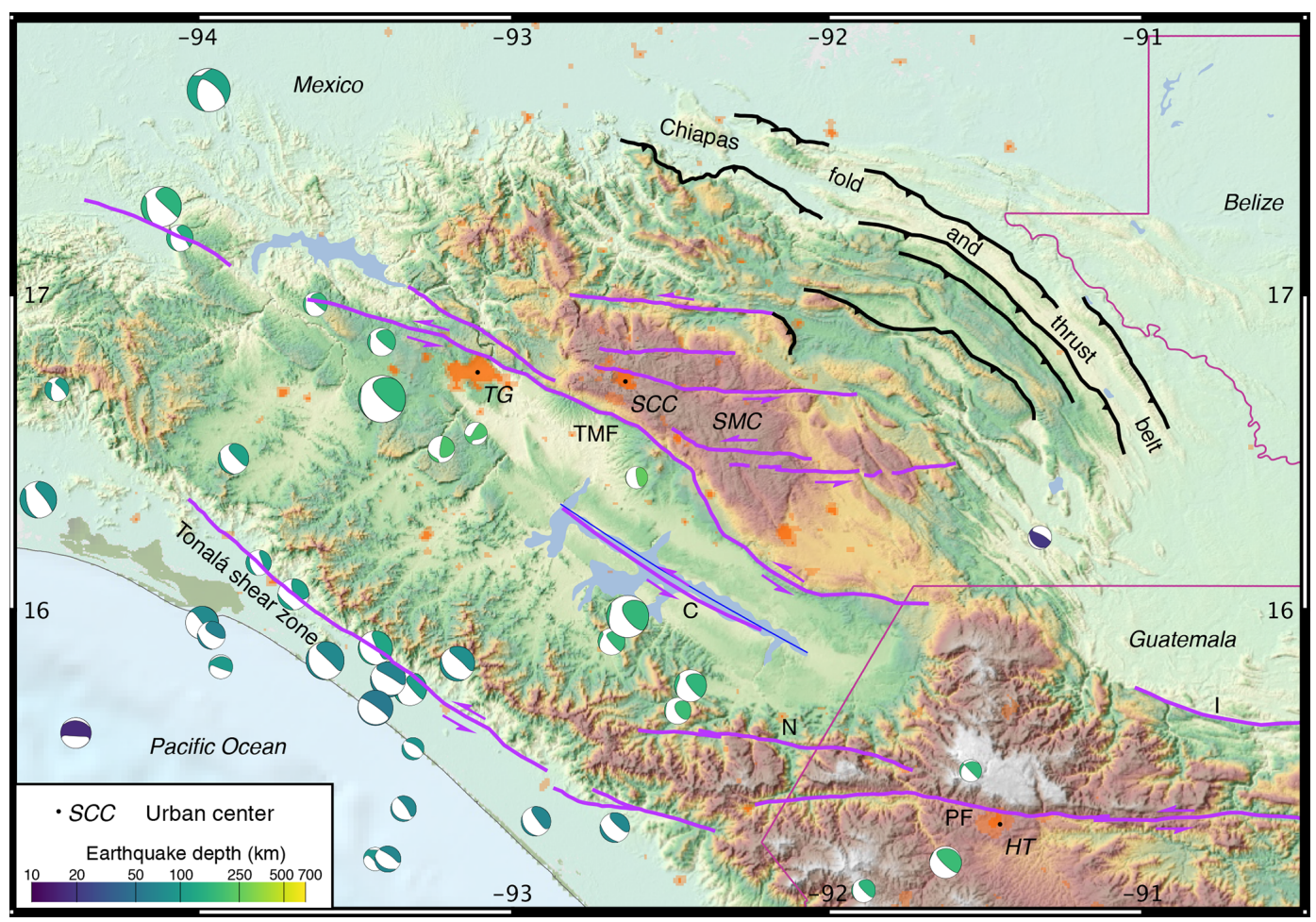

Figure 2. Active faults in Chiapas and vicinity. Symbology the same as in Fig. 1. TMF is the Tuxtla-Malpaso fault. I is the Ixcán fault. $\mathrm{C}$ is the Concordia fault. N is the Necta fault. PF is the Polochic fault. SMC is Sierra Madre de Chiapas. TG is Tuxtla Gutiérrez. SCC is San Cristóbal de las Casas. HT is Huehuetenango. Focal mechanisms are from the Global Centroid Moment Tensor catalog (Ekström et al., 2012).

ture in the continental crust and links to the Swan IslandOriente transform faults in the oceanic crust to the east. Deformation is transtensional south of the Motagua-Polochic fault zone through northern Costa Rica, with distributed normal faulting in the highlands of northern Central America as well as in the backarc of Central American volcanic arc. Rapid (10-15 $\mathrm{mm} \mathrm{a}^{-1}$ ) dextral shear occurs on faults located close to the volcanic arc, which separate the Central American forearc from the Caribbean continental crust.

\subsubsection{Chiapas}

The Chiapas region of southern Mexico and neighboring northwestern Guatemala (Fig. 2) is the southernmost part of the North American plate and contains distributed sinistral and reverse faulting in the Sierra Madre de Chiapas and the Chiapas fold and thrust belt to the northeast (Witt et al., 2012) as well as the sinistral faults associated with the Tonalá shear zone (e.g., Molina-Garza et al., 2015).

The Sierra Madre de Chiapas contains a set of W-NWstriking sinistral faults through the highlands and along its southwestern margin (Witt et al., 2012). The range-bounding faults make up the Tuxtla-Malpaso fault system. In the high interior, the strike-slip faults are $\mathrm{W}$-striking and merge on their eastern ends with contractional structures. The north- ern and eastern Sierra Madre de Chiapas faults are lower and composed of discrete ranges making up the Chiapas fold and thrust belt.

NW-striking sinistral faulting may also occur in the central depression along the Concordia fault system. However, most of this fault system is under the Presa La Angostura reservoir, making assessment of its activity challenging. It is considered sinistral by most workers (e.g., Meneses-Rocha, 2001; Guzmán-Speziale, 2010; Witt et al., 2012), but the Mexican active fault dataset of Villegas et al. (2017) lists it as dextral; this may be due to interpretation of focal mechanisms consistent with dextral slip on NW-striking fault planes, though these are deep $(>150 \mathrm{~km})$ and perhaps in the subducting slab rather than the crust.

Slip rates in the region are poorly constrained. Witt et al. (2012) estimate strike-slip rates on the Tuxtla-Malpaso fault system of 5-8 $\mathrm{mm} \mathrm{a}^{-1}$ averaged over the Pliocene to present (i.e., $\sim 6$ Ma to present), and they attribute a $1902 M=7.2$ event to the Tuxtla fault; however, Guzmán-Speziale (2010) considers this event (or an additional 1902 event) to have been a $M=7.6-7.8$ earthquake on the Concordia fault, following extensive reports of damage along that fault zone. He also reports additional events in the region since 1500 . Regardless of the records of historical seismicity, GPS velocity vectors indicate a strain of only a few millimeters per annum 


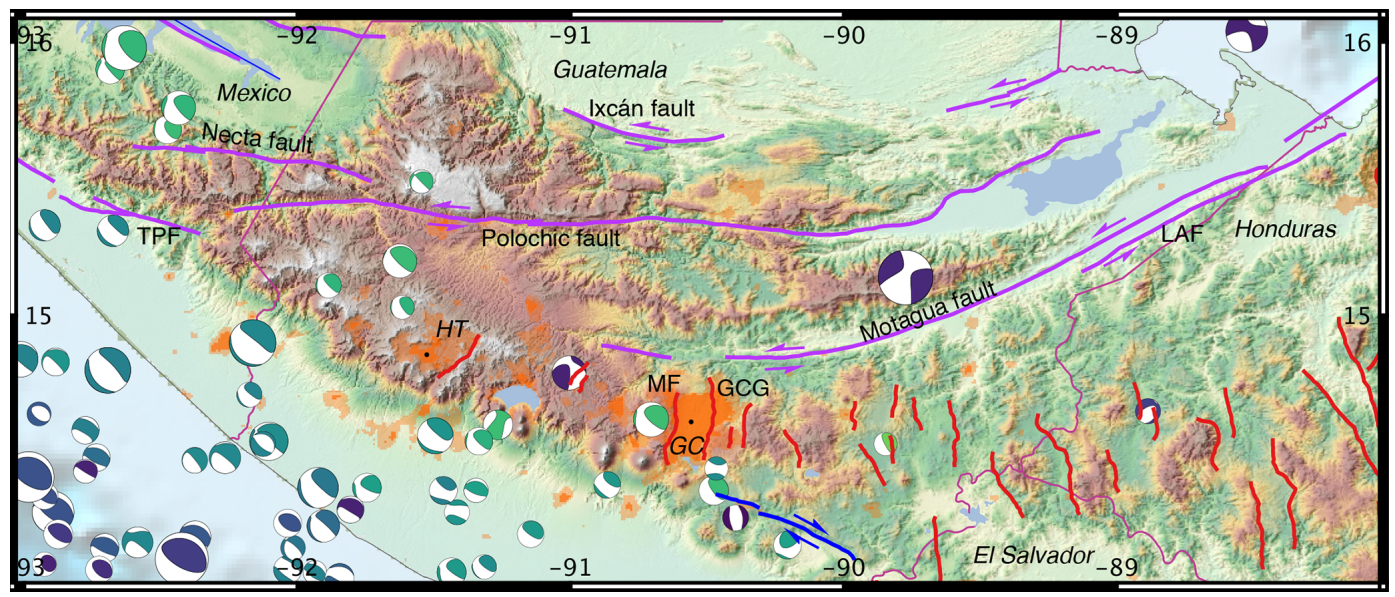

Figure 3. The Motagua-Polochic fault zone. MF is the Mixco fault. GCG is the Guatemala City graben. TPF is the Tonalá-Polochic fault zone. LAF is the Los Amates fault. HT is the Huehuetenango. GC is Guatemala City.

across the entire region, so individual fault slip rates may be low (Kreemer et al., 2014; Ellis et al., 2019).

To the southwest, an enigmatic structure known as the Tonalá shear zone separates the highlands of the Chiapas massif from the low Pacific Coastal Plain. The structure was originally a Miocene sinistral-reverse fault zone that assisted in the uplift of the Chiapas massif (Molina-Garza et al., 2015) and may be currently active. The kinematics of the structure are unclear but hinge on the configuration of the CaribbeanNorth American-Cocos triple junction, as different configurations make different kinematic predictions for the Tonalá shear zone. Recent analysis of this problem concludes that slip from the sinistral Polochic fault may be transferred to the Tonalá shear zone (Authemayou et al., 2011). Following this logic, we consider the structure to be sinistral, with highly uncertain slip rates. However, given its geometry and location above a subduction zone, the fault could easily have a large reverse component.

Though the population in Chiapas is lower than some other locations in the study area, the faults are very understudied given their length and proximity to population centers. For example, the capital and largest city, Tuxtla Gutiérrez, is built on top of the Tuxtla-Malpaso fault system, which may be the most rapidly slipping fault in the region (Witt et al., 2012). To our knowledge, no fault in Chiapas has received any sort of neotectonic or focused geodetic study.

\subsubsection{Motagua-Polochic fault zone}

The continental segment of the North American-Caribbean plate boundary is expressed as the Motagua-Polochic fault system (Fig. 3). This sinistral fault system is made up of two dominant faults, the Motagua fault in the southeast and the Polochic fault in the northwest of the fault zone. Additionally, parallel sinistral faults are present (such as the Los Amates and Ixcán faults), and both the Motagua and
Polochic faults themselves show topographic evidence for many strands, though most authors choose the strands we have mapped as the main active structures.

Slip rates on the Motagua-Polochic fault system are high in the east and decrease to the west. The Motagua fault seems to accommodate most of the slip in the fault system. A recent GPS study (Franco et al., 2012) indicates slip rates of $\sim 20 \mathrm{~mm} \mathrm{a}^{-1}$ for the central Motagua fault, which is close to the total Caribbean-North American relative plate velocity (DeMets et al., 2010). To the west, slip on the Motagua fault drops progressively. Some of this slip is probably picked up along the Polochic fault to the north, estimated at 2$5 \mathrm{~mm} \mathrm{a}^{-1}$ (Lyon-Caen et al., 2006; Authemayou et al., 2012; Franco et al., 2012; Ellis et al., 2019), but much of the decrease seems to be linked to E-W extension of the Central Highlands in the south. (During the review period for this article, a thorough geodetic study by Ellis et al., 2019, was published that supports this suggestion.)

The Motagua fault ruptured in the 4 February $1976 M_{\mathrm{w}}=$ 7.6 earthquake. Nearly the entirety of the fault, well over $200 \mathrm{~km}$, slipped in the event (Bucknam et al., 1978); slip also occurred on the Mixco fault that bounds the western end of the Guatemala City graben (Plafker, 1976), which is kinematically linked to the Motagua fault. The geomorphic expression of active slip on the Motagua fault in $30 \mathrm{~m}$ SRTM data becomes more ambiguous west of the Mixco fault, which suggests that the two faults work together to accommodate eastward relative motion of crust to their south and east and that the kinematic linkage displayed during the 1976 event is a recurrent phenomenon. Despite the apparent westward decrease in slip rate along the Motagua fault (e.g., Franco et al., 2012; Ellis et al., 2019), the highest measured slip in the 1976 earthquake was in the west, between El Progreso and the Guatemala City graben, where $2-3 \mathrm{~m}$ of displacement was observed, as compared to the $\sim 1 \mathrm{~m}$ of displacement observed consistently along the hundred kilo- 
meters of rupture to the east (Bucknam et al., 1978). This pattern may be explained by larger and less frequent slip in the west as compared to the east, but a considerable paleoseismic effort is required to test this hypothesis.

The Polochic fault parallels the Motagua fault some $45 \mathrm{~km}$ to its north and extends over a hundred kilometers farther west. Though the Polochic fault is longer than the Motagua fault, its slip rate is lower, estimated at $4-5 \mathrm{~mm} \mathrm{a}^{-1}$ for the central segments using both neotectonic and geodetic techniques (Lyon-Caen et al., 2006; Authemayou et al., 2012; Franco et al., 2012; Ellis et al., 2019). Slip rates may decrease progressively west, as they do over the entire fault system.

The western end of the Polochic fault terminates into two groups of fault splays, the Necta fault in the north and a set of faults here called the Tonalá-Polochic fault system that links these two structures. None of these faults have received any tectonic study. Nonetheless we consider all of these faults to be sinistral based on their geometries. Slip rates are similarly unknown but based on the regional deformation field are not expected to be above $2 \mathrm{~mm} \mathrm{a}^{-1}$ for any structure.

Two relatively small sinistral faults exist to the north of the eastern Polochic fault, the Ixcán fault (Guzmán-Speziale, 2010) and an unnamed structure along strike of that structure to the east near the village of Las Conchas, where small to moderate earthquakes have clustered over the past several decades.

Nearby subparallel faults to the south of the Motagua fault do not seem to be active. The Jocotán-Chamelecón fault system, for example, does not display the same topographic evidence for neotectonic slip as the faults discussed above (e.g., Schwartz et al., 1979), so it has not been included in this compilation and is not shown on the map to avoid confusion about its activity.

\subsubsection{Central Highlands}

South of the Motagua-Polochic fault system, a broad elevated zone exists through much of Guatemala and Honduras (Fig. 4). East-west extension of $\sim 10 \mathrm{~mm} \mathrm{a}^{-1}$ (Rodriguez et al., 2009; Franco et al., 2012; Kreemer et al., 2014) is accommodated through an array of north-trending grabens spanning the breadth of the subcontinent. The grabens are best expressed at high elevations (where vertical stress from topography may be highest, increasing differential stress in the crust) and are generally interpreted to be kinematically linked to the Motagua fault so that extension to the south of the Motagua fault along these grabens causes an eastward increase in the slip rate on the fault (e.g., GuzmánSpeziale, 2001). However, of the 10-15 graben systems, only the largest two (the Guatemala City and Sula grabens) display a hard kinematic linkage with the Motagua fault. Therefore we suspect that the mid-elevation region immediately south of the Motagua fault undergoes distributed extension. Indeed, this zone displays tectonic geomorphology (i.e., subdued basin and range topography) consistent with many small normal faults, but evidence for active slip localized on major normal faults is lacking in the SRTM data and seismic catalogs.

Slip rates on individual structures are generally unknown. The three systems generally considered the most active, and with the most prominent topographic expressions, are the Guatemala City graben, the Ipala graben and the Honduras depression (comprising the Sula and Comayagua grabens and possibly extending to the transtensional Gulf of Fonseca to the south). Though there are no known geologic slip rate studies of these faults, recent geodetic block modeling by Ellis et al. (2019) gives some insight. Their block model contains a block for the highlands of Honduras, a block for the highlands of Guatemala to the west (separated from the Honduran block by the Ipala graben), and a block for the area immediately north and west of the Motagua-Polochic fault system. They find extension rates of $2 \pm 1 \mathrm{~mm} \mathrm{a}^{-1}$ for the Honduran highlands that do not appear to be strongly localized on any given fault, extension rates about $2 \mathrm{~mm} \mathrm{a}^{-1}$ across the Ipala graben, a $5 \pm 2 \mathrm{mma}^{-1}$ extension in the Guatemalan block between the Ipala and Guatemala City grabens, about a $5 \mathrm{~mm} \mathrm{a}^{-1}$ extension across the Guatemala City graben, and another $2-6 \mathrm{~mm} \mathrm{a}^{-1}$ extension in the highlands west of Guatemala City. These rates of extension sum to nearly $20 \mathrm{~mm} \mathrm{a}^{-1}$.

East-striking normal and possibly sinistral faults line the northern coast of Honduras (Rogers and Mann, 2007). The Nombre de Dios range is the uplifted footwall of the northdipping La Cieba normal fault. The Río Viejo fault lies within the eastern part of range and is interpreted by us as sinistralnormal in the west and sinistral farther east. The La Esperanza normal fault lies farther south, on the southeastern margin of the Aguán River valley. Rogers and Mann (2007) interpret additional faults in this valley, including the Aguán and Lepaca sinistral faults, but to us the fault traces look too degraded for our consideration of them as active structures.

Normal and sinistral faulting continues offshore to the north towards the Swan Islands fault zone. A large normal fault south of Roatán Island separates the island (on a horst) from the Tela Basin, which lies between Roatán and the mainland (Rogers and Mann, 2007; Cox et al., 2008). On Roatán itself, Cox et al. (2008) have mapped the Flowers Bay fault, which has uplifted corals on the island and is a potential source of the August 1956 tsunami. They interpret the fault as normal to the southwest and sinistral to the northeast. They also find rates of uplift of the island to be $\sim 3 \mathrm{~mm} \mathrm{a}^{-1}$.

The Central Highlands are bound to the east by the Guayape fault, a very linear NE-striking structure that is nearly continuous across the breadth of Honduras. However, geologic mapping discussed by Gordon and Muehlberger (1994) indicates that no units younger than Miocene are demonstrably offset; this is consistent with our interpretation of the fault as an inactive structure, given the lack of instrumental seismicity, geodetic strain or any evidence of deformation of Quaternary units in the base datasets. (Note 


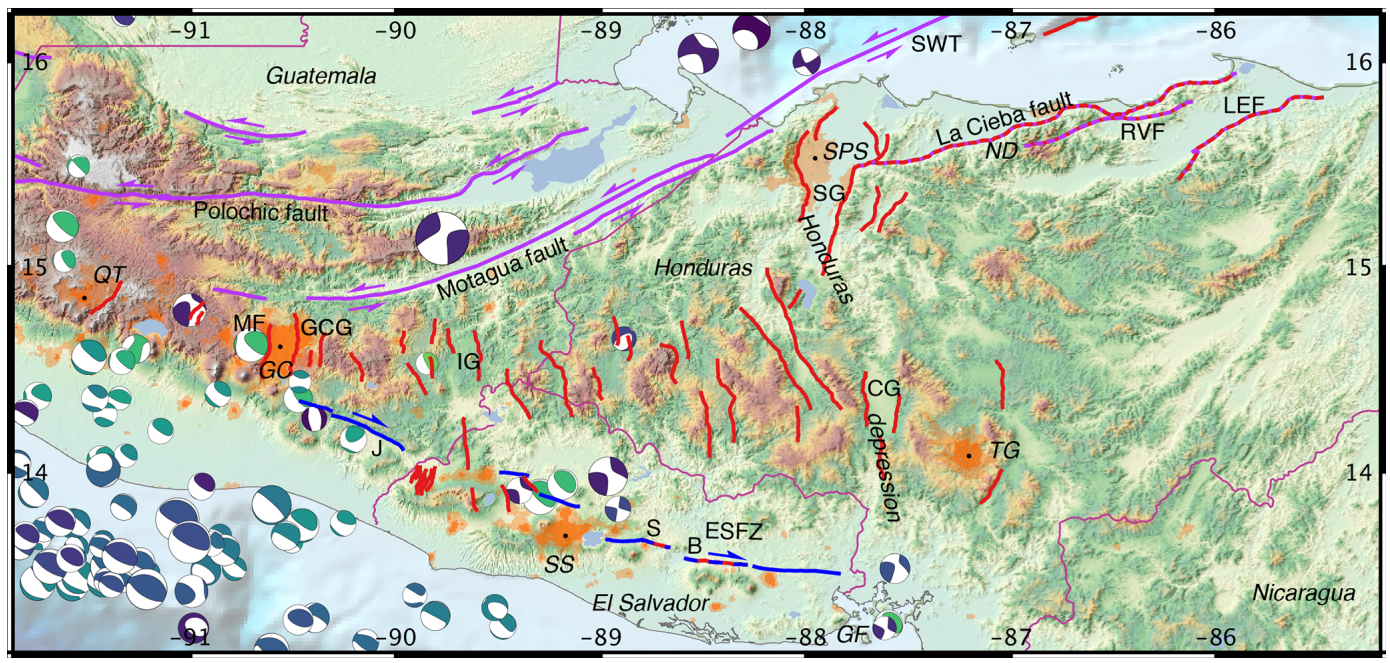

Figure 4. Active faults in the Central Highlands. SWT is the Swan Islands transform. LEF is the La Esperanza fault. RVF is the Río Viejo fault. SG is the Sula graben. IG is the Ipala graben. GCG is the Guatemala City graben. MF is the Mixco fault. CG is the Comayagua graben. $\mathrm{J}$ is the Jalpatagua fault. ESFZ is the El Salvador fault zone. $\mathrm{S}$ is the San Vicente segment (ESFZ). B is the Berlin segment (ESFZ). ND is the Nombre de Dios range. SPS is San Pedro Sula. GF is the Gulf of Fonseca. SS is San Salvador. GC is Guatemala City. QT is Quetzaltenango.

that this is not the conclusion arrived at by Gordon and Muehlberger, 1994; supporting our interpretation, the fault is not included in the active fault traces of Rogers and Mann, 2007.)

\subsubsection{Central American forearc}

The Central American forearc extends from Chiapas south for $>1200 \mathrm{~km}$ to the Costa Rican-Panamanian border (Fig. 5). The forearc itself does not display much evidence for substantial internal deformation along faults; instead, strain and seismicity are localized on NW-striking dextral strike-slip faults that run along (underneath or slightly inboard of) the Central American volcanic arc and transtensional zones where this fault system contains releasing bends.

From a purely kinematic perspective (disregarding the forces that drive deformation), the fault system along the volcanic arc may be thought of as a conjugate strike-slip system to the Motagua-Polochic fault zone, with the northwestern Caribbean plate undergoing extrusion or tectonic escape (e.g., McKenzie, 1972) to the east. The trailing edge of the extruding block undergoes extension, producing the graben system in the Central Highlands which is accommodated through slip rate and magnitude gradients on the kinematically linked Motagua-Polochic and volcanic arc fault zones such that slip on those fault systems increases to the east and southeast, respectively (e.g., Burkart and Self, 1985; Gordon and Muehlberger, 1994; Authemayou et al., 2011; Ellis et al., 2019).

The northwesternmost mapped fault of the volcanic arc fault system is the Jalpatagua fault (Carr, 1976) in western Guatemala. This dextral fault is somewhat segmented, es- pecially to the northwest near the Guatemala City graben (Carr, 1976), but becomes more well-defined and linear to the southeast. It is easily traceable in the topographic data near the Guatemala-El Salvador border, where it intersects small normal faults (and possibly northeast-striking sinistral faults as in Carr, 1976, though we did not observe them clearly enough to map them). The fault is along strike of the volcanic arc to the northwest but inboard of the proximal volcanic arc segment, as in El Salvador. The slip rate on the Jalpatagua fault system increases from $1.4 \mathrm{~mm} \mathrm{a}^{-1}$ in the northwest near the Mexican border to $7.6 \mathrm{~mm} \mathrm{a}^{-1}$ in the southeast near the Salvadorian border (Ellis et al., 2019).

Dextral faulting continues along strike to the northwest, as evidenced by a shallow $M_{\mathrm{w}}=6.2$ strike-slip earthquake in 1991 near Lake Atitlán (White and Harlow, 1993), but faulting is not sufficiently well expressed geomorphically to map with confidence. Furthermore, as noted by White and Harlow (1993), the northwestern segment of the volcanic arc produces less seismicity.

Farther southeast in El Salvador, forearc-bounding faulting is expressed as the El Salvador fault system (e.g., White and Harlow, 1993; Martínez-Díaz et al., 2004; Corti et al., 2005), which is a series of disconnected dextral to dextralnormal faults in the backarc. The El Salvador fault system is the best-studied part of the volcanic arc fault system. Due in part to the locally dry climate and distance from the volcanic arc, the fault traces are quite apparent and most authors map them similarly. Slip rates on these faults seem to be generally constant along strike at $7-12 \mathrm{~mm} \mathrm{a}^{-1}$ : Staller et al. (2016) find rates from 7 to $12 \mathrm{~mm} \mathrm{a}^{-1}$ on four geodetic transects spanning most of the fault zone, though they give a much lower value $\left(2 \mathrm{~mm} \mathrm{a}^{-1}\right)$ for the easternmost segment. In this 


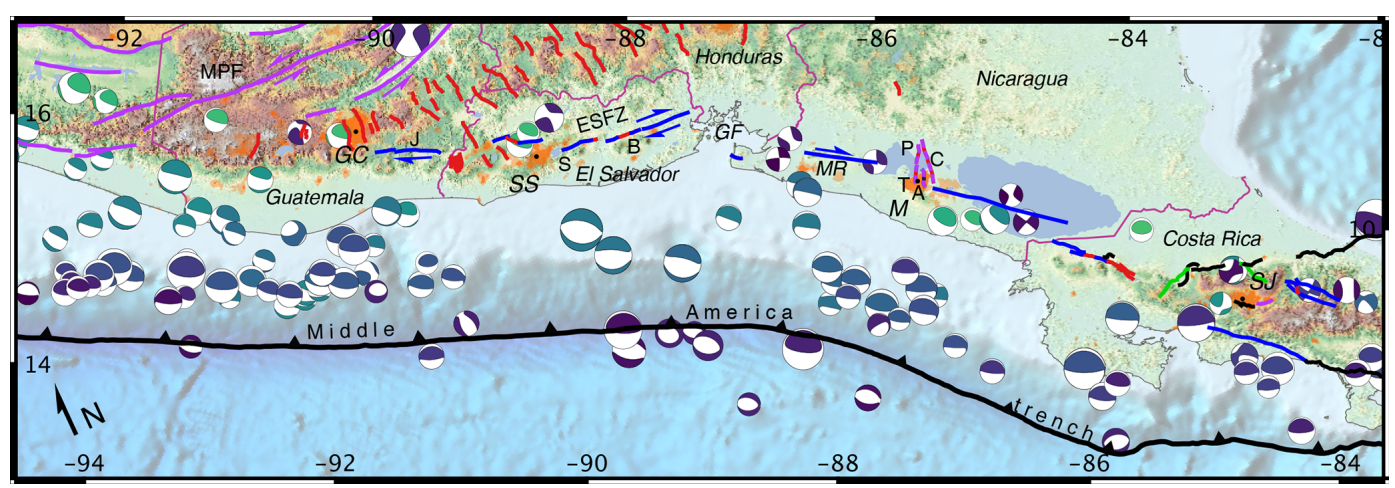

Figure 5. The Central American forearc. MPF is the Motagua-Polochic fault zone. $\mathrm{J}$ is the Jalpatagua fault. ESFZ is the El Salvador fault zone. S is the San Vicente segment (ESFZ). B is the Berlin Segment (ESFZ). P is the Punta Huete fault. C is the Cofradía fault. A is the Aeropuerto fault. T is the Tiscapa fault. GC is Guatemala City. MR is the Marabios range. M is Managua. SH is San José.

last transect, the total rate of shear across El Salvador remains at $\sim 10 \mathrm{~mm} \mathrm{a}^{-1}$, but some of the strain may be taken up on small faults near the coast. Additionally, we suspect that deformation may be more complicated here, nearing the Gulf of Fonseca. Corti et al. (2005) find a late Quaternary slip rate of $11 \mathrm{~mm} \mathrm{a}^{-1}$ for the central-eastern Berlin segment, which is slightly higher than the estimates of Staller et al. (2016).

Observations of instrumental, historical and paleoseismological earthquakes along the El Salvador fault zone reveal plentiful moderate seismicity. The most well-constrained event is the $2001 M_{\mathrm{w}}=6.6$ event on the San Vicente segment (Martínez-Díaz et al., 2004), which had a maximum surface displacement of $60 \mathrm{~cm}$ (Canora et al., 2010). Additional $M \sim 6$ events have occurred in 1917, 1919, 1951 and 1986 on the fault zone (White and Harlow, 1993; Martínez-Díaz et al., 2004). Paleoseismological studies of the San Vicente segment show surface-breaking ruptures with displacements of $0.5-5 \mathrm{~m}$ per event and a mean recurrence interval of 800 years (Canora et al., 2012).

The Gulf of Fonseca is a shallow depression at the junction of El Salvador, Honduras and Nicaragua. Following recent work (Funk et al., 2009; Alvarado et al., 2011), we view the gulf as part of a transtensional stepover in the Middle American forearc fault system. Faulting here seems to be somewhat distributed, with volcanic centers coinciding with small N-trending rifts. Strike-slip faulting is less clearly observed in the topography or bathymetry data, but strike-slip focal mechanisms are found throughout the gulf, especially towards the mainland. Ellis et al. (2019) model the gulf and region west of it on the Salvadorian mainland as a single internally deforming block occupying an extensional stepover in the arc and bound by dextral faults in the north and south. Slip rates on the northern strand decrease west to east from 9 to $2 \mathrm{~mm} \mathrm{a}^{-1}$ over the length of the block, while for the southern strand they increase from 1 to $9 \mathrm{~mm} \mathrm{a}^{-1}$. The block itself extends at $12 \pm 6 \mathrm{~mm} \mathrm{a}^{-1}$, consistent with observations of distributed normal faulting in the region (e.g., Alvarado et al., 2011).
The location and nature of faults continuing into Nicaragua are also unclear, though given the abundant seismicity, deformation is certainly present. Geodetic studies (e.g., Turner et al., 2007; Styron, 2008; Alvarado et al., 2011) indicate that the northwestern Nicaraguan fault translates $\sim 15-20 \mathrm{~mm} \mathrm{a}^{-1}$ with respect to the stable Caribbean plate. This is the fastest arc-parallel motion observed in Central America. The location of the faults accommodating the forearc translation is not obvious, but most evidence points towards a zone of dextral shear located underneath the volcanic arc (called the Marabios range). The Marabios range is remarkably linear, with the major active volcanic centers located within $1 \mathrm{~km}$ of a straight line through the range. Furthermore, seismicity extends continuously along the range, not only along the active volcanoes, and focal mechanisms are consistent with dextral slip on a vertical fault aligned with the volcanic arc. These focal mechanisms have been interpreted to reflect sinistral "bookshelf" faulting on structures orthogonal to the arc (LaFemina et al., 2002), but this interpretation is not supported by the alignment of lowermagnitude seismicity and no evidence for these faults is present away from the southwestern terminus of the Marabios range, on the margins of the Managua graben, which is widely interpreted as a releasing stepover in the system (as described below). GPS geodetic data are also best explained by a dextral fault underneath the arc (Styron, 2008). Confusingly, there is very little geomorphic evidence for dextral shear in the forearc or backarc; the most convincing is the presence of low hills near El Congo that are interpreted as a small restraining stepover in between the Marabios range and Cosigüina Volcano (Funk et al., 2009). Styron (2008) suggested that the very high productivity of the Marabios volcanoes is sufficient to bury evidence of strike-slip faulting, but this is not a very satisfying conclusion. The only obvious surficial evidence of faulting is $\mathrm{N}$-trending grabens emanating from the volcanic vents, but these are short and likely insufficient to accommodate $1-2 \mathrm{~cm}^{-1}$ of forearc translation. The collocation of the volcanic arc and the strike-slip fault 
is surely not coincidental, but the direction of causation is uncertain: it is possible that the existence of the magmatic conduits resulted in a plane of weakness in the crust that was reactivated. Alternatively, the fault may have provided an easy path for magma migration. Funk et al. (2009) suggested that the Marabios range volcanoes lie along older normal faults now reactivated as dextral, based on interpretation of geophysical data collected in Lake Managua. Those authors do not favor the hypothesis of a single, throughgoing strikeslip fault under the arc, instead calling for the reactivation of many small north-striking normal (or normal-dextral) faults that may act as a broad shear zone. Unfortunately, any suggestion of dip-slip faulting taking up $\sim 15 \mathrm{~mm} \mathrm{a}^{-1}$ dextral shear would result in vertical separation rates of at least several millimeters per annum at minimum, which would leave a much larger mark in the landscape than the quite subdued offsets produced by the observed $\mathrm{N}$-striking normal faults. Though we have chosen to represent the structure as a single dextral fault under the arc, it is worth keeping in mind that this representation produces the largest contiguous fault surface of the several competing hypotheses and therefore the largest maximum magnitude for earthquakes along this segment of the volcanic arc. Other hypotheses positing smaller, distributed faults predict commensurately smaller maximum earthquake magnitudes. If the latter hypotheses are more accurate, it may mean that the recent $M_{\mathrm{w}} \sim 6$ dextral events on either edge of the volcanic chain (e.g., Suárez et al., 2016) are representative of seismicity in the dextral shear zone, and much larger events are not possible.

The Managua area contains an array of N-NE-striking transtensional faults that are typically interpreted as a releasing stepover in the arc-parallel strike-slip fault system (e.g., Brown et al., 1973; Cowan et al., 2002; Funk et al., 2009), although these faults extend farther into the backarc than the inferred zone of dextral shear; the faults may link with a potentially active graben near Sébaco. We have included four faults in the Managua area: the Tiscapa, Aeropuerto and Cofradía (also called the Tipitapa) faults on the southern and eastern shores of Lake Managua and the Punta Huete fault in the north. The latter may be the northern continuation of the Tiscapa fault. These faults are the longest and most geomorphically clear of the many faults in the zone and likely to be the most seismically active. The 1972 Managua earthquake $\left(m_{\mathrm{b}}=5.6, M_{\mathrm{S}}=6.2\right)$ occurred on the Tiscapa fault (e.g., Brown et al., 1973). Though field studies (Brown et al., 1973; Freundt et al., 2010) suggest several times more rapid vertical displacement than horizontal displacement on the Tiscapa fault, the focal mechanism from the 1972 event indicates purely sinistral slip on a very steeply $\left(80-90^{\circ}\right)$ east-dipping fault plane. This may be an expression of strain partitioning on closely spaced faults or changes in slip kinematics on the same plane during different events.

A zone of inferred dextral strike slip continues to the southeast into Lake Nicaragua along the volcanic arc. The evidence for and against dextral strike slip along this seg- ment of the arc is similar to that in the Marabios range, with the additional caveat that most of the area is underwater. Seismicity from the Nicaraguan Institute of Territorial Studies (INETER) catalog (compiled by Styron, 2008, from the INETER website, at: https://www.ineter.gob.ni, last access: in early 2008; these data are no longer available at the original source) is less continuous along the arc than in the Marabios range. Based on interpretation of geophysical and stratigraphic data, Funk et al. (2009) suggest that the southern Nicaraguan volcanic arc also overlies one or more normal faults now reactivated as strike-slip faults.

\subsubsection{Southern Central America}

To the south of Lake Nicaragua into Costa Rica, active faulting seems to change in style and kinematics, though observations are sparse. In northern Costa Rica, trench-perpendicular strain changes from extensional to contractional (Fig. 6) and is distributed throughout the narrow isthmus. On the northeastern flank of the Cordillera Central, active faults are mostly reverse (e.g., Montero et al., 2013) as well as a few of indeterminate kinematics. The NW-striking reverse faults continue through the Limón area, where the Cordillera Central merges with the northwestern Cordillera Talamanca and where the $1991 M_{\mathrm{w}}=7.7$ Limón thrust event was located (Suárez et al., 1995). Reverse faulting continues offshore to the southeast, where it forms the active thrust front of the northern Panama deformed belt, which wraps around southern Central America to its juncture with Colombia. Additional active faulting may be present between the northeastern flank of the Cordillera Talamanca and the coast in far-eastern Costa Rica and western Panama; the Limón Basin area (south of the 1991 earthquake) is often shown on petroleum-oriented maps with generally $\mathrm{N}$-dipping thrusts (e.g., Barboza et al., 1997), which may be optimally oriented in the modern stress field.

Between the Central and Talamanca Cordilleras, the Riosucio and Atirro River faults (Montero et al., 2013) likely make up most of the hazard to San José, though smaller faults are present throughout the area. It is unclear if the southwestern range front of the Cordillera Talamanca has active faulting, though faulting is documented along the Pacific Coast along the Fila Costeña fault system. These faults seem to be dextral (or dextral-reverse) in the northwest, transitioning into reverse in southern Costa Rica. Faulting along this trend becomes sinistral in western Panama. Geodetic studies show interseismic strain replicating this pattern (LaFemina et al., 2009).

Shortening rates on the Fila Costeña thrusts have been thought to be extremely high: Sitchler et al. (2007) estimate $\sim 40 \mathrm{~mm} \mathrm{a}^{-1}$ shortening, which would place the basal thrust as the second fastest-slipping continental thrust on Earth after the Ramu-Markham thrust system in Papua New Guinea, where the New Britain megathrust comes ashore (e.g., Abbott et al., 1994; Wallace et al., 2004; Koulali et al., 2015), 


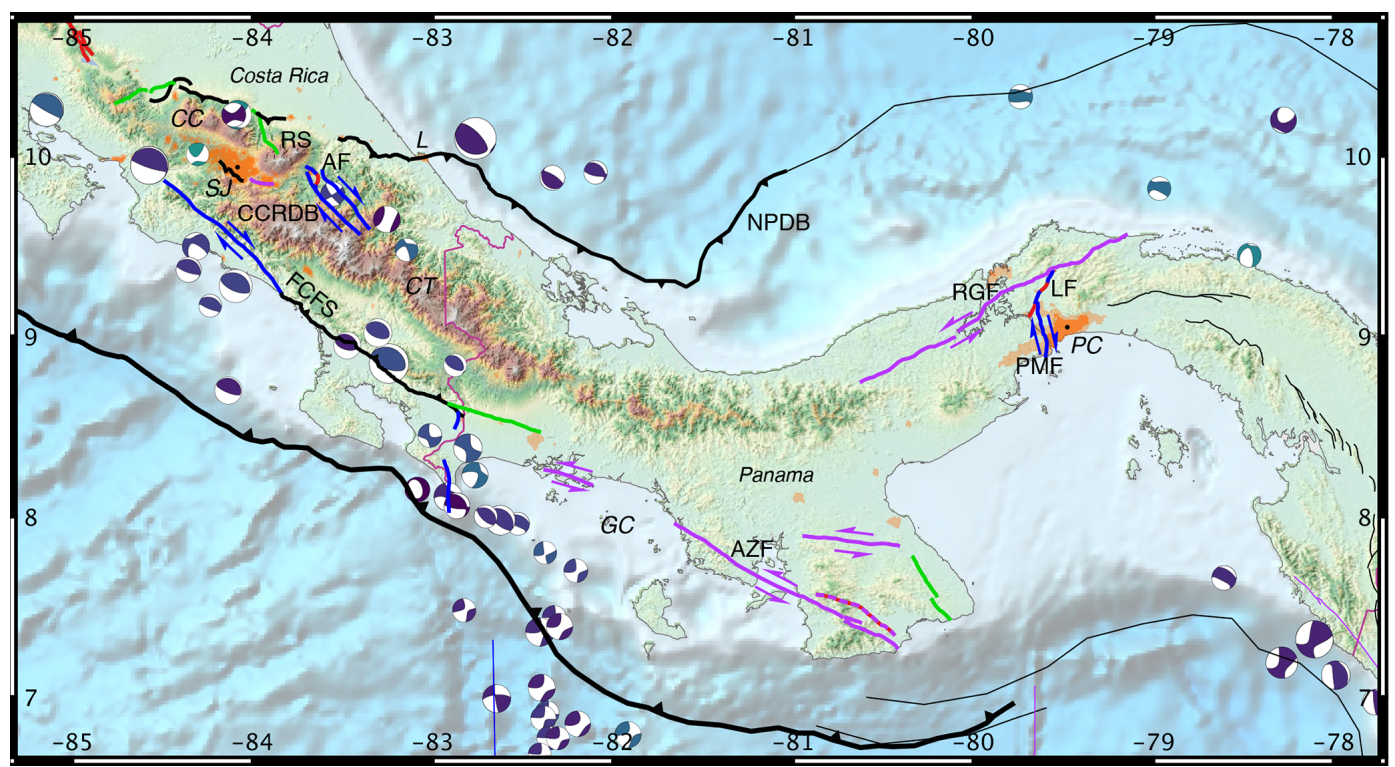

Figure 6. Active faults of Costa Rica and Panama. RS is the Riosucio fault. AF is the Atirro fault. CCRDB is the central Costa Rica deformed belt. FCFS is the Fila Costeña fault system. RGF is the Río Gatún fault. LF is the Limón fault. PMF is the Pedro Miguel fault. AZF is the Azuero fault.

and twice as fast as the main Himalayan thrust in Nepal (Lavé and Avouac, 2000; Ader et al., 2012), which would then become the third fastest-slipping (to the best of our knowledge). Though it is part of a plate boundary region, it is not the actual subduction interface (being $100 \mathrm{~km}$ into the overriding plate), and this would make it far and away the fastestslipping intraplate fault in the world. As Sitchler et al. (2007) estimate the shortening rate using balanced cross sections and a time of initiation based on a plate reconstruction (rather than directly dated marker beds), this rate needs independent confirmation before it can be used for PSHA, and so we do not include it in the database; nonetheless, their work does provide strong evidence of rapid deformation in the area.

Additional active faulting on small faults (many below our minimum cutoff) is distributed throughout the country in the central Costa Rica deformed belt (e.g., Marshall et al., 2000). This zone likely accommodates much of the geodetic velocity gradient between the rapidly deforming crust above the Cocos ridge, where upper-plate velocities are in excess of $50 \mathrm{~mm} \mathrm{a}^{-1}$, relative to the stable Caribbean plate, and the northern part of the country, which (though poorly instrumented) moves essentially with the Caribbean plate (e.g., LaFemina et al., 2009). It is unclear what the maximum size of earthquakes produced on distributed faults in the central Costa Rica deformed belt is, though crustal seismicity is frequent throughout the region.

Two major fault systems have been studied in central Panama. The longest is the northeast-striking sinistral Río Gatún fault, which may slip as fast as a $6-10 \mathrm{~mm} \mathrm{a}^{-1}$, decreasing slightly to the southwest (Rockwell et al., 2010b, a). The dextral Limón and Pedro Miguel faults extend south from the central Río Gatún fault. The Pedro Miguel fault in particular is a major hazard to both Panama City and the Panama Canal infrastructure, as it passes within a few kilometers of each and has a slip rate of $3.5-8 \mathrm{~mm} \mathrm{a}^{-1}$ (Rockwell et al., 2010b, a). Bennett et al. (2014), however, find far lower slip rates on these faults, with $0.2-1 \mathrm{~mm} \mathrm{a}^{-1}$ net slip on the Río Gatún fault and $1.4-1.9 \mathrm{~mm} \mathrm{a}^{-1}$ on the LimónPedro Miguel fault chain, from a GPS study of a 4-year time series; they explain the difference between the geodetic and geologic rates as being from earthquake cycle effects lowering the modern geodetic rates relative to geologic rates averaged over multiple earthquake cycles. Therefore we use the geologic rates of Rockwell et al. (2010a).

Farther east into the Darién zone of Panama and northwest Colombia, onshore deformation is evident from seismicity, but the lightly populated jungle region has received little field study. Structures active in the late Neogene such as the Sansón Hills fault (Mann and Corrigan, 1990) clearly deform late Miocene strata but may not be active today (Coates et al., 2004). Offshore deformation also takes place along the frontal thrusts of the northern and southern Panama deformed belts as well as in the fracture zones of the Cocos and Nazca plates.

Southwestern Panama contains active strike-slip faults as well. The sinistral Azuero fault cuts through the Azuero Peninsula and may slip up to $9 \pm 2 \mathrm{~mm} \mathrm{a}^{-1}$ (Rockwell et al., 2010b), though given the lack of seismic or geomorphic evidence of slip this rapid, we view this as an upper bound (though rapid, enigmatic arc-parallel strike-slip faults seem to be ubiquitous in the Middle American forearc). A few unstudied ancillary faults are observed in topographic data, but 
kinematics and slip rates are uncertain. Along strike to the northwest of the Azuero fault, Camacho (2003) has mapped a set of sinistral faults that may be the continuation of the Azuero fault across the Gulf of Chiriquí.

\subsubsection{Middle America trench}

Subduction of the Cocos plate underneath the Caribbean plate occurs at the Middle America trench. This megathrust is very seismically active due to the rapid plate convergence rate, which varies between roughly 75 and $85 \mathrm{~mm} \mathrm{a}^{-1}$ along strike (e.g., DeMets, 2001). Subduction is for the most part perpendicular to the trench, but due to geometric changes it is slightly oblique in places; though minor $\left(<30^{\circ}\right)$, the arcparallel component reaches $\sim 15 \mathrm{~mm} \mathrm{a}^{-1}$ in Nicaragua because of the large magnitude of the overall velocity vector. This may be a driver of dextral translation of the Central American forearc (DeMets, 2001; Turner et al., 2007).

Coupling on the trench is highly variable. In Costa Rica, GPS geodesy clearly indicates strong locking of the trench and rapid strain accumulation, which may be enhanced by subduction of the Nazca ridge (e.g., LaFemina et al., 2009). However, to the northwest in Nicaragua and El Salvador, the geodetic data show little motion consistent with coupling at the trench, a hypothesis supported by mechanical modeling of the plate interface (e.g., Alvarado et al., 2011). Nonetheless, "moderate" subduction zone earthquakes of $M<7.7$ have occurred in the past several decades on the less coupled part of the trench, including the $1992 M_{\mathrm{w}}=7.6$ Nicaragua event (Kanamori and Kikuchi, 1993) and the $2012 M_{\mathrm{w}}=7.3$ El Salvador event (Borrero et al., 2014).

\subsection{Antilles}

The islands of the Antilles are historically broken into two groups, the Greater Antilles (including Cuba, Jamaica, Hispaniola and Puerto Rico) and the Lesser Antilles, which is the chain of small, mostly volcanic islands stretching from the Virgin Islands near Puerto Rico in the north to Trinidad and Tobago in the south near Venezuela. This distinction applies to the geology as well: the Greater Antilles are located astride the northern, dominantly strike-slip portion of the North American-Caribbean plate boundary, while the Lesser Antilles are for the most part arc volcanoes and other subduction-related islands formed by the subduction of North and South American oceanic lithosphere under the Caribbean plate at the Antilles trench. The patterns of active faulting reflect these plate boundary configurations; faulting in the Greater Antilles is dominated by strike-slip faults with dip- or oblique-slip structures at stepovers (Fig. 7), while faulting in the Lesser Antilles is mostly localized on the Antilles megathrust, with minor upper-plate structures accommodating arc-parallel extension and translation of forearc blocks (Fig. 8).

\subsubsection{Cuba, Jamaica and the Swan Islands transform}

The Caribbean-North American plate boundary offshore to the east of Central America is the sinistral Swan Islands transform, which extends to the Cayman spreading center south of the Cayman islands (Fig. 1). Relative plate motion here is about $19 \mathrm{~mm} \mathrm{a}^{-1}$ (DeMets et al., 2010) and seems to be accommodated exclusively on the Swan Islands transform with the exception of some structures in the Tela Basin near Roatán that accommodate the slight component of extension across the plate boundary (these are discussed in Sect. 3.1.3). Therefore we ascribe the full relative plate motion rate to the Swan Islands transform. Where it is a single strand, this is $\sim 19 \mathrm{~mm} \mathrm{a}^{-1}$, and where it is broken into two strands (around Swan Island), we split the rate somewhat arbitrarily; the southern branch is more or less continuous to the east, so we give it two-thirds of the total rate, and the remainder is applied to the northern branch.

The Swan Islands transform ruptured in a $M_{\mathrm{w}}=7.3$ event in 2009. Graham et al. (2012) modeled the coseismic slip distribution from GPS and teleseismic data and showed continuous rupture from onshore Guatemala and Honduras not far east of the eastern terminus of the 1976 Motagua rupture (e.g., Plafker, 1976) to east of the Swan Islands. Slip was located on the northern rather than the southern branch at the Swan Islands split. The rupture was $\sim 350 \mathrm{~km}$ long, and maximum slip was found to be $\sim 1 \mathrm{~m}$.

The Swan Islands transform terminates in the east at the Cayman spreading center, which extends at $10-15 \mathrm{~mm} \mathrm{a}^{-1}$ (Leroy et al., 2000; Hayman et al., 2011; Benford et al., 2012a), though like most mid-ocean ridges, the seismogenic crust is probably very thin, and it may not produce moderate to large earthquakes. To the east, the North AmericanCaribbean strike-slip boundary is broken into two parallel strike-slip faults, the Oriente fault in the north and the Walton fault zone in the south; the intervening oceanic crust is the western portion of the Gônave microplate (e.g., Rosencrantz and Mann, 1991; DeMets and Wiggins-Grandison, 2007).

The Oriente fault west of Cuba is the major plate-bounding structure, slipping at $\sim 10-15 \mathrm{~mm} \mathrm{a}^{-1}$ and accommodating $60 \%-80 \%$ of the total relative plate motion (e.g., Benford et al., 2012a; Symithe et al., 2015). The fault system undergoes an extensional stepover off the southwestern coast of Cuba (Fig. 7) and farther east becomes transpressional once again (e.g., Calais and de Lepinay, 1991). N-S convergence across the plate boundary here occurs in the Santiago deformed belt. This contractional zone bears structural resemblance to an accretionary prism and may contain several stacked thrusts (Calais and de Lepinay, 1991; Leroy et al., 2015), but given the lack of detailed information on potential out-of-sequence thrust activity we choose to represent the zone with a single, north-dipping basal thrust. The major strike-slip Oriente fault trace continues to northern Hispaniola through the Windward Passage, where it merges with the 


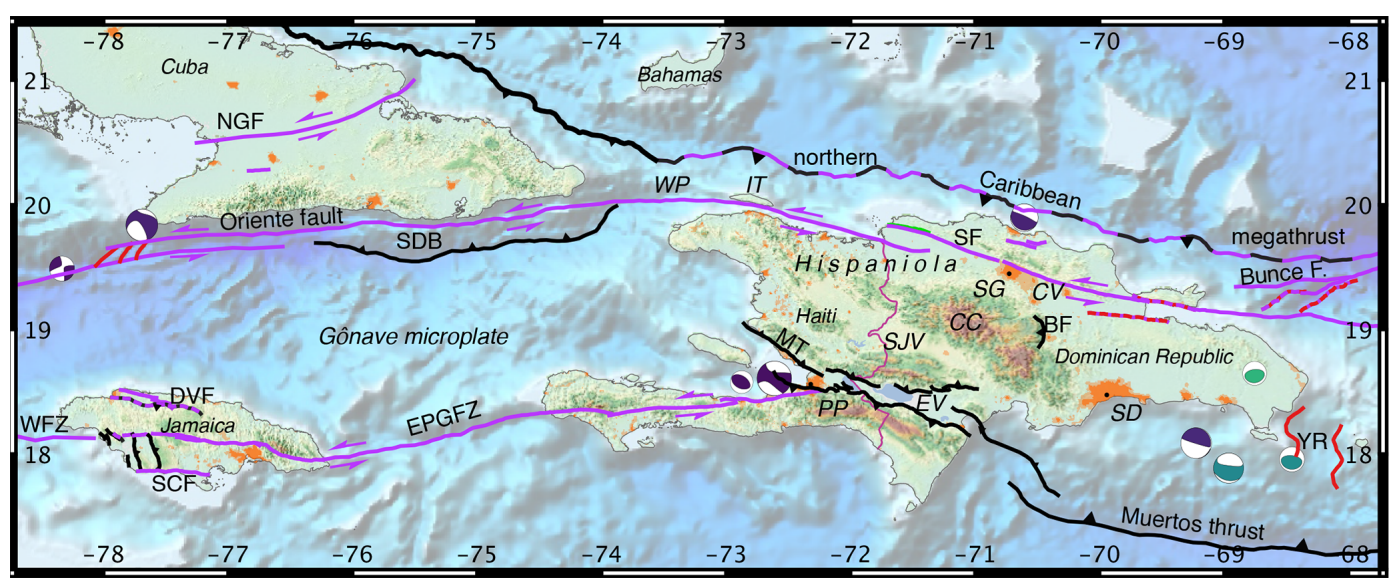

Figure 7. Active faults of the Greater Antilles. NGF is the Nipo-Guacanayabo fault zone. SDB is the Santiago deformed belt. SF is the Septentrional fault. BF is the Bonao fault. MT is the Matheux thrust. EPGFZ is the Enriquillo-Plantain Garden fault zone. YR is the Yuma rift. DF is the Duanvale fault. SCF is the southern coast fault. WFZ is the Walton fault zone. WP is the Windward Passage. IT is Tortuga Island. SG is Santiago de los Caballeros. CV is the Cibao Valley. CC is Cordillera Central. SJV is the San Juan Valley. SD is Santo Domingo. $\mathrm{PP}$ is Port-au-Prince. EV is Enriquillo Valley.

Septentrional fault system (Calais et al., 1992; Leroy et al., 2015).

Within the interior of Cuba, several zones of seismicity, inferred as faults or fault zones, cross the island. Two of these, the Pinar del Río fault in northwestern Cuba (e.g., Gordon et al., 1997) and the Nipo-Guacanayabo fault in southeastern Cuba, were included in this compilation. Some other notable fault zones exist, such as the Camagüey and La Trocha faults (e.g., García et al., 2003), but these lack sufficient topographic expression to map as throughgoing structures consistently with the criteria applied elsewhere in the GEM fault databases. Slip rates and kinematics on these faults are all unknown, and the lack of geodetic data from Cuba makes it very difficult to quantify internal strain on the island. Offshore to the northeast of Cuba, the northern Cuban fault separates Cuban crust from The Bahamas platform. The northern Cuban fault is mapped here as a reverse fault, given its geomorphology, but current kinematics are unknown. Farther north, the Cay Sal fault is present between Cay Sal and Androes Island, and a $40 \mathrm{~km}$ long scarp evident in bathymetric and seismic data suggests neotectonic activity (Kula, 2014).

To the south of the western Oriente fault, the parallel Walton fault zone accommodates the remainder of the North American-Caribbean motion, some $4-7 \mathrm{~mm} \mathrm{a}^{-1}$ (Benford et al., 2012b) (though Symithe et al., 2015, give it a higher rate, $9-10 \mathrm{~mm} \mathrm{a}^{-1}$ ). As with the Oriente fault, this structure becomes more complicated to the east near Jamaica and may split into active northern and southern strands (Rosencrantz and Mann, 1991); however, in the absence of available bathymetric data of sufficient resolution to map these splays, we draw the structure as a single strike-slip fault intersecting central-western Jamaica.

Jamaica itself is the location of a restraining bend between the Walton fault zone to the west and the Enriquillo-Plantain
Garden fault zone to the east. Faulting on the island occurs on east-striking sinistral faults and north-striking reverse faults (Benford et al., 2015). The most rapid slip seems to be in an east-west zone through the center of the country (the MinhoCrawle River fault, the Cavaliers fault and the Plantain Garden fault), which slips at $5 \pm 2 \mathrm{~mm} \mathrm{a}^{-1}$ (Benford et al., 2012b; Koehler et al., 2013); rapid slip on the northern Duanvale fault zone does not seem to be supported by the geodetic data. Some slip in the central faults may be transferred to the south through the reverse faults to the sinistral southern coast fault or to other (possibly undocumented) faults on the island. This interpretation of distributed slip, primarily by Koehler et al. (2013), is in light of paleoseismic evidence indicating no Holocene (and possibly no mid-Quaternary to late Quaternary) seismicity on the Plantain Garden fault. Nonetheless, it is generally agreed that faulting to the east of the Plantain Garden fault is localized on the offshore segment of the Enriquillo-Plantain Garden fault (e.g., Benford et al., 2012b; Leroy et al., 2015).

Slow sinistral-normal deformation may take place in the western Caribbean plate off the shore of Nicaragua and southwest of Jamaica. Carvajal-Arenas and Mann (2018) link Eocene through Pliocene extensional and strike-slip structures bordering the southern extended margin of the Central American continental crust in a N-NE-trending fault system. Though the region off the shore of Nicaragua has moderatemagnitude seismicity, geodetic studies limit the total strain to under a few millimeters per annum (e.g., Symithe et al., 2015).

\subsubsection{Hispaniola and the Mona rift}

The Oriente and the Enriquillo-Plantain Garden faults continue to northern and southern Hispaniola, respectively 
(Fig. 7). The Oriente fault lies just off the shore of the northern coast of Haiti, south of the island of La Tortue (Tortuga), and then reaches the shore in the northeastern Dominican Republic, very close to the Haitian border (e.g., Leroy et al., 2015). Slip on the Oriente fault north and west of Haiti may be slightly slower than farther west $\left(9-10 \mathrm{~mm} \mathrm{a}^{-1}\right)$, as some strike-slip motion may be taken up on the northern Hispaniola fault (Benford et al., 2012a), part of the northern Caribbean megathrust.

At its eastern terminus, the Oriente fault is kinematically linked to the Septentrional fault, which is a parallel $>250 \mathrm{~km}$ long (E-SE-striking) sinistral fault cutting across northern Hispaniola and continuing east (Mann et al., 1998; Prentice et al., 2003). The western end of the Septentrional fault is about $20 \mathrm{~km}$ north of the Oriente fault, on the other side of the Cibao Valley. This alluvial valley is covered by Quaternary sediments and may be underlain by additional faults between the Septentrional and Oriente faults that have no surface expression. Nonetheless, older sediments on the southern valley sides do not display deformation suggestive of continued slip on the Oriente fault into the interior of the island. The Septentrional fault is estimated to slip at $10-11 \mathrm{~mm} \mathrm{a}^{-1}$ based on geodetic block modeling (Benford et al., 2012a; Symithe et al., 2015).

The Enriquillo-Plantain Garden fault enters Hispaniola at its westernmost point, crossing the length of the Tiburon Peninsula (also called the southern peninsula of Haiti). The fault has a sinistral slip rate of $5-7 \mathrm{~mm} \mathrm{a}^{-1}$ and may be transpressional; geodetic modeling ranges from contraction of 0 (Symithe et al., 2015) to $5 \mathrm{~mm} \mathrm{a}^{-1}$ (Benford et al., 2012a). The geomorphology of the fault zone suggests mild transpression, as the fault zone runs through the highest topography of the peninsula. The fault is also segmented here; its trace suggests a slight break in the west, north of Les Cayes, and a more prominent extensional stepover south of Miragôane. Farther east towards Port-au-Prince, contractional structures are more evident in the landscape and seismicity (Wang et al., 2018). The devastating 2010 Haiti earthquake is thought to have occurred on the previously unknown Léogâne fault, a north-dipping blind reverse-oblique structure associated with the Enriquillo fault system (Calais et al., 2010); as the fault does not seem to have a mappable trace, we cannot include it in this dataset.

Contraction occurs on thrust faults through a valley stretching from Port-au-Prince (Haiti) in the west through Barahona (Dominican Republic) in the east, called the Plains of the Cul-de-Sac in Haiti and the Nieba or Enriquillo Valley in the Dominican Republic (Wang et al., 2018). This valley is bordered on its northern and southern margins by active thrusts, as evidenced by seismicity (Rodriguez et al., 2018) and geomorphology: the signs of sedimentation and subsidence in the footwall as well as fault propagation folds deforming Quaternary sediments attest to rapid slip on these faults. Saint Fleur et al. (2015) map several of these thrusts in Haiti from field and remote-sensing observations and extend the mapping to the west into Port-au-Prince Bay. Northwest of the city, the $80 \mathrm{~km}$ long Matheux thrust (Pubellier et al., 2000) poses a seismic and tsunami hazard to the region. Into the Dominican Republic, the faults have not received geological study, but their characteristics remain the same as those along strike in Haiti. Geodetic slip rates through the zone indicate 3-8 $\mathrm{mm} \mathrm{a}^{-1}$ contraction (Benford et al., 2012a; Symithe et al., 2015), but it is not clear how this is distributed onto individual structures.

Though Haiti has long been identified as the location of a restraining bend in the northern Caribbean strike-slip boundary (e.g., Mann et al., 1984), there is a lack of known active faults in central Hispaniola. Although bedrock fault traces are readily observable in digital elevation data in the Cordillera Central and the San Juan Valley to the south, there is little sign of Quaternary offset. The San Juan Valley in particular shows the hanging walls of the range-bounding reverse faults to be uplifted and actively eroding instead of subsiding and accumulating sediment. Furthermore, river traces and Quaternary landforms do not appear to be modified by active faulting. The major exception to this is the Bonao fault on the east of the Cordillera Central, which is a fairly short, west-dipping reverse fault that has a very sharp trace and a footwall basin that seems to be filling rather than eroding. However, slip rates on this structure are unknown, and its separation from regional structures may mean that any slip on it is rather slow. Though the newer geodetic block models place the boundary between the Gônave plate and blocks to the east through the San Juan Valley (e.g., Symithe et al., 2015), it is suggested here from the patterns of active faulting that relative motion between blocks is taken up through distributed deformation in western Hispaniola and through the Cul-de-Sac-Enriquillo Valley in the south; the latter representation is also used by researchers such as Benford et al. (2012a).

Between Hispaniola and Puerto Rico, both the Septentrional and Enriquillo fault zones terminate offshore into more enigmatic structures. The Septentrional fault zone splits into the transtensional Bunce fault (which strikes northeast and merges with the Puerto Rico trench) and the northtrending Mona rift northwest of Puerto Rico (e.g., ten Brink et al., 2004; Grindlay et al., 2005b; Hippolyte et al., 2005; Mondziel et al., 2010). The thrust of the eastern Enriquillo Valley continues southeastward into the Muertos thrust, a north-dipping thrust where Caribbean oceanic crust underthrusts the continental and transitional crust of the eastern Greater Antilles (Mauffret and Leroy, 1999; Granja Bruña et al., 2009).

This transition marks a change in the nature of the North American-Caribbean plate boundary. To the west of the Mona rift (and the Yuma rift to its southwest), the "geologic" plate boundary fault is the northern Hispaniola thrust, where the crust of the Bahama Bank underthrusts (or has underthrust) the Hispaniola block (e.g., Dolan et al., 1998); however, modern slip on this fault as evident in geodetic data is 
$\sim 2 \mathrm{~mm} \mathrm{a}^{-1}$, less than $10 \%$ of the relative plate motion. Instead, the Hispaniola block deforms internally via the aforementioned structures and also moves at moderate rates with respect to the stable oceanic crust of the Caribbean to its south, mostly along the Muertos thrust (Symithe et al., 2015). To the east of the Mona rift, the situation is different. The plate-bounding Puerto Rico trench (and likely the Bunce and Bowin faults in the hanging wall) accommodates most of the relative plate motion (e.g., Symithe et al., 2015). Internal deformation of Antilles crust, represented by the Puerto RicoVirgin Islands block, is minimal, and slip rates on the Muertos thrust are similarly low, at $<2 \mathrm{~mm} \mathrm{a}^{-1}$ (e.g., Jansma and Mattioli, 2005; Benford et al., 2012a). In addition to demarcating the different styles of deformation to the east and west, the Mona and Yuma rifts also serve as the zone of strain between the two domains: extension across the rifts between the Puerto Rico and Hispaniola blocks is $3-4 \mathrm{~mm} \mathrm{a}^{-1}$ (Jansma and Mattioli, 2005; Benford et al., 2012a; Symithe et al., 2015). Chaytor and ten Brink (2010) mapped an intricate network of small- to moderate-length normal faults in the transition zone between the Mona and Yuma rifts. The complexity of faulting here suggests either distributed oblique extension or multiple phases of extension. The largest faults are $\sim 70 \mathrm{~km}$ long and capable of $M \leq 7$ earthquakes. Kinematic linkage between the Mona rift and the Cerro Goden fault in western Puerto Rico is also likely based on marine geophysical data and interpretation (e.g., Grindlay et al., 2005a; Hippolyte et al., 2005).

\subsubsection{Offshore faulting}

Some of the longest faults in the northeastern Caribbean are found in the Mona rift and the Bunce and Bowin fault systems of the northern plate margin. These structures are located in deep water (4-8 km depth) and are consequently poorly understood (Fig. 8). Nonetheless they likely accommodate the strike-slip component of North AmericanCaribbean convergence and may slip rapidly (up to $15 \mathrm{~mm} \mathrm{a}^{-1}$ ), although direct slip rate measurements are not currently possible. The southeastern Bowin fault zone appears to have some contractional component, while the northern and western Bunce fault zone has some extensional component. Given the very slow (and probably dextral) slip rates on the faults extending southeast from the Mona rift in Puerto Rico (discussed below) it is likely that the majority of slip from the Septentrional fault is transferred to these structures.

The Puerto Rico trench may not be a source of major interplate thrust earthquakes; ten Brink and López-Venegas (2012) find that the trench does not accumulate significant contractional strain, though sinistral slip is possible.

Farther west, north of Hispaniola, the plate interface becomes contractional again due to a northward bend in the strike (making it transpressional). The convergence of thick, buoyant continental crust of the Bahama Bank with the plate interface (here called the northern Hispaniola thrust) is the only part of the entire megathrust where contractional strain is being accommodated. Symithe et al. (2015) model coupling ratios of $0.5-1$ over much of this boundary, leading to elastic strain accumulation rates consistent with $\sim 2 \mathrm{~mm} \mathrm{a}^{-1}$ of reverse slip, which may be higher in the west towards Cuba, but there are no geodetic data in Cuba to make accurate estimates.

\subsubsection{Puerto Rico and the Virgin Islands}

Puerto Rico has several E-SE-striking fault zones that cut through the interior of the island and are fairly well expressed topographically (Fig. 8). These are, from east to west, the great northern Puerto Rico fault zone, the great southern Puerto Rico fault zone and the Cerro Goden fault. Despite the names, these faults are in an east-west belt along the island. The faults show more deformation in Eocene and older rocks than in Neogene rocks (Mann et al., 2005a), and their expression in the landscape is largely a consequence of this Paleogene activity. The modern kinematics of these faults is also unclear. GPS studies (e.g., Jansma and Mattioli, 2005) indicate that strain rates across Puerto Rico are below the noise level, something of a rarity in this part of the world. The geometry of the Cerro Goden and great southern Puerto Rico fault zone at first glance appear to be part of a chain of faults from the Septentrional fault in the Dominican Republic through the Mona rift, across Puerto Rico and into the Anegada rift. However, assuming sinistral-oblique kinematics for the chain of faults (based on the Septentrional fault and Caribbean-North American relative motion), the Mona rift would represent a right step in a left-lateral system, which would be a restraining bend. This is clearly not consistent with the bathymetric and seismic expression of extension across the Mona rift.

If the Cerro Goden and great southern Puerto Rican faults are linked to the Mona rift in the classic strike-slip-tostepover fashion, this implies right slip along the Puerto Rican faults, which is more consistent with reconnaissance field observations by Mann et al. (2005b) indicating dextralnormal slip on the Cerro Goden fault. This latter interpretation is hard to place in a regional tectonic framework, but given the low strain rates, the most appropriate response to the question "What are the Puerto Rican faults doing?" may be "Not much." For this reason, the lack of inclusion of terrestrial Puerto Rican faults in geodetic block models is understandable and probably accurate.

Holocene activity on these faults is poorly documented, in part because of an apparent lack of investigation. Work by Mann et al. (2005b) on the Cerro Goden fault near Mayagüez provides support for slow, dextral-normal slip on that structure. Better evidence is found on the short $(<10 \mathrm{~km})$ southern Lajas fault. Prentice and Mann (2005) map and trench a scarp on the southern Lajas fault and find evidence for one oblique-slip earthquake $\sim 5040$ a BP on a near-vertical fault. Roig-Silva et al. (2013) find additional evidence for Quater- 


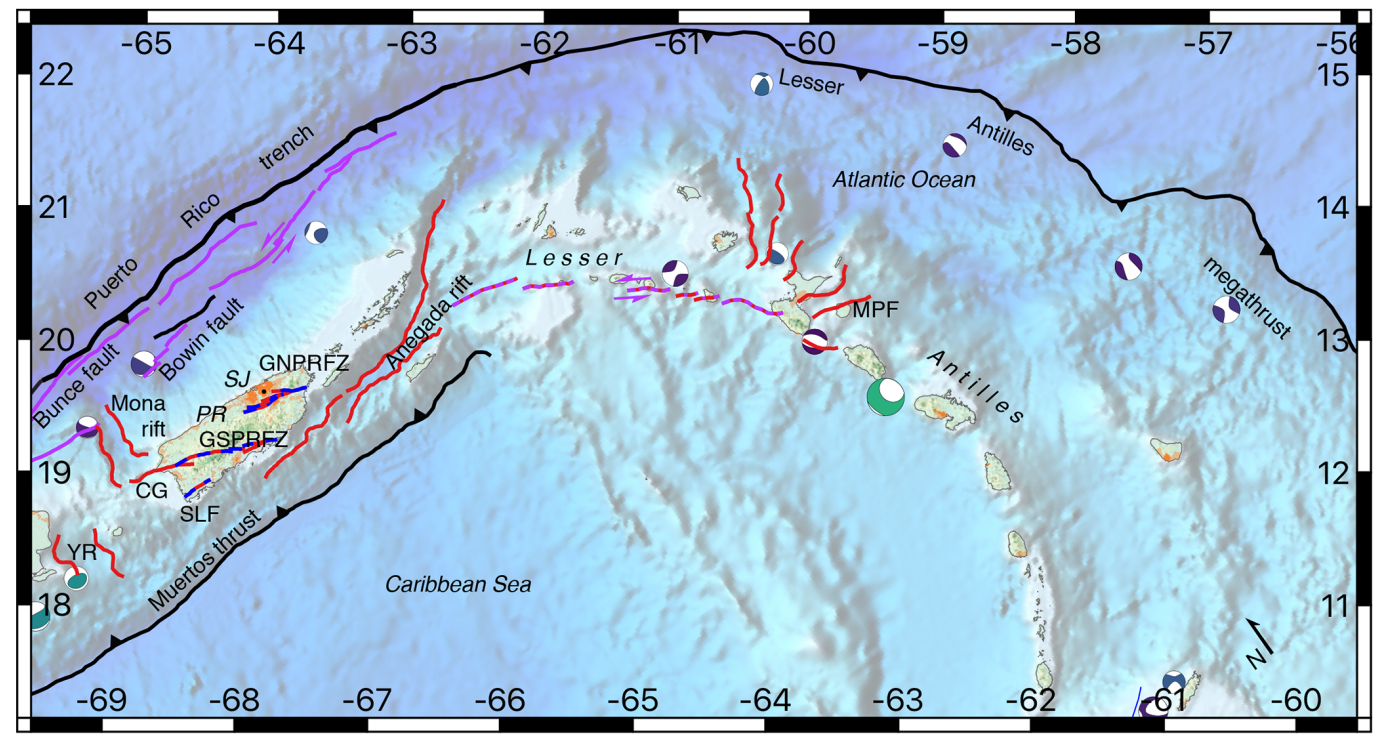

Figure 8. Active faults of the Lesser Antilles. YR is the Yuma rift. CG is the Cerro Goden fault. SLF is the southern Lajas fault. GSPRFZ is the great southern Puerto Rico fault zone. GNPRFZ is the great northern Puerto Rico fault zone. MPF is the Morne Trois Pitons fault. SJ is San Juan.

nary faulting on the southwestern coast of Puerto Rico, but the mapped faults are too small to be included in this compilation. Farther east, Piety et al. (2018) mapped and trenched the Salinas and southeastern great southern Puerto Rico fault zone, documenting two earthquakes offsetting 7.4-10.3 ka sediments.

The southeastern margin of the relatively rigid Puerto Rico-Virgin Islands crustal block is the Anegada rift, a normal-sinistral rift separating this crust with the Lesser Antilles. This rift is estimated to open obliquely at $>$ $1.5 \mathrm{~mm} \mathrm{a}^{-1}$ (Benford et al., 2012a; Liu and Wang, 2015), though some variability exists in the relative amounts of normal to sinistral motion.

\subsubsection{Lesser Antilles}

Faulting in the Lesser Antilles occurs on three sets of faults that are all typical components of variably oblique subduction systems. The first is the Lesser Antilles megathrust, which slips at $18-20 \mathrm{~mm} \mathrm{a}^{-1}$ (e.g., Symithe et al., 2015). The megathrust reaches the ocean floor $>200 \mathrm{~km}$ to the east of the islands of the Lesser Antilles, which move more or less with the stable Caribbean plate geodetically. This makes estimating locking on the megathrust difficult. Small to moderate seismicity is common in the north but decreases south towards Venezuela; the accretionary prism becomes extremely thick here, which may lubricate the trench or otherwise suppress seismicity.

The second and third sets of faults are found in the upper plate of the central and northern Lesser Antilles (Fig. 8). One is a set of normal faults that are perpendicular to the arc and trench that extend from the arc towards the trench, and the other is a set of arc-parallel normal-sinistral faults located near the modern arc (e.g., Feuillet et al., 2011). These accommodate fragmentation and translation of the arc crust due to variably oblique convergence.

The normal faults cut not only the modern arc but also the thick crust of the former outer arc that exists east of the active volcanic islands. As they are mostly under the sea, the study of them is minimal, though Feuillet et al. (2004) found a vertical slip rate of $\sim 0.5 \mathrm{~mm} \mathrm{a}^{-1}$ on the southern Morne Trois Pitons fault. Though escarpments reminiscent of normal faults are found between the blocks of the inactive outer arc to the northwest of Antigua, shallow seismicity decreases substantially, and the scarps are less well-defined; therefore they are not mapped here. This is consistent with theory and observations from other zones of variably oblique convergence with an arcuate upper plate (e.g., McCaffrey and Nabelek, 1998; Styron et al., 2011): arc-parallel extension is concentrated in the center of the arc, where the arc-parallel velocities are low but the velocity gradient is highest, and the margin-parallel strike-slip faults continue, likely with increasing slip rates, away from the center of the arc.

None of these structures have been mapped in the southern half of the Lesser Antilles. Some of this may be due to insufficient study and the thick blanket of sediments from the Orinoco River, but this region is relatively aseismic. Though seismicity is quite low on the interface, geodetic investigation by Graham et al. (2018) indicates moderate to high locking on the megathrust interface, consistent with research by Gomez et al. (2018) that demonstrates considerable shortening within the accretionary prism. This suggests that elas- 

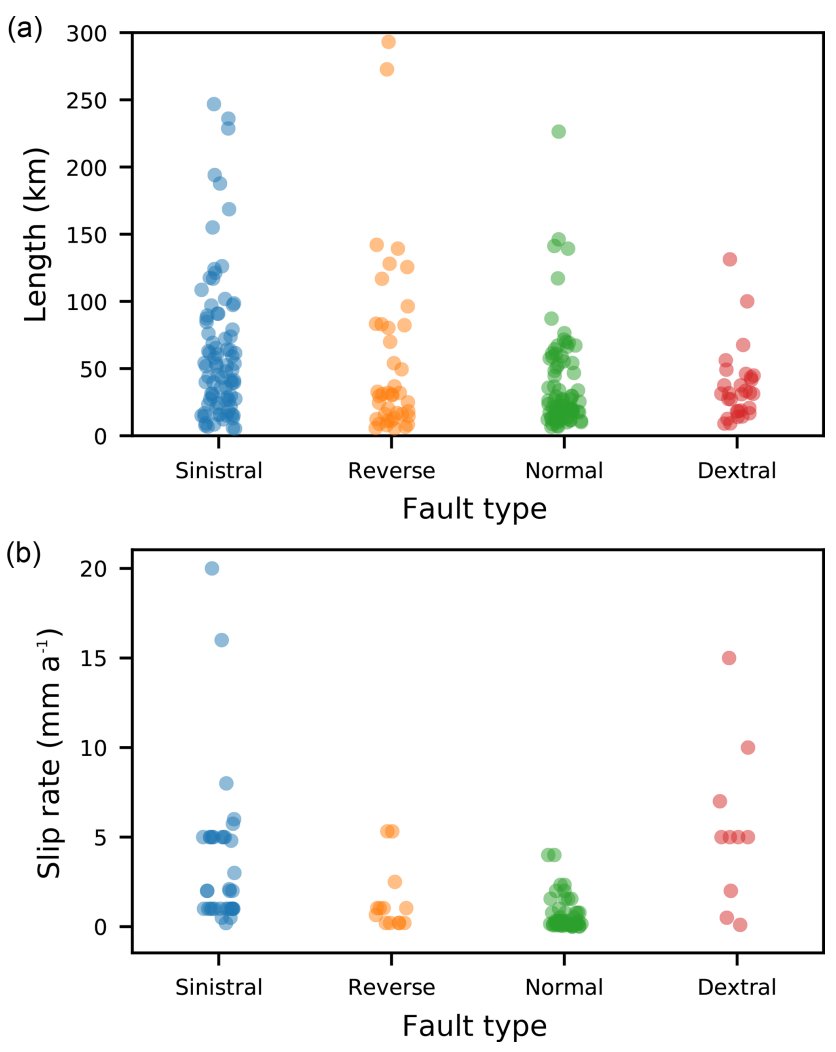

Figure 9. Strip plots of fault length (a) and slip rate (b) for faults in the CCAF-DB, by major fault type (i.e., "dextral-normal" would be considered "dextral"), discounting oceanic plate boundaries. The scatter in the $x$ axis is simply jitter to minimize overprinting of symbols.

tic strain accumulation occurs and may be released in large megathrust earthquakes.

\section{Discussion and conclusions}

The CCAF-DB contains fault traces throughout the Caribbean and Central America, excluding areas covered by other catalogs such as northern South America. Onshore fault coverage is good, and there are few large or populated regions where seismic activity is expected but fault coverage is lacking. Offshore faulting is obviously more challenging to study, and coverage is necessarily more sparse.

The distribution of fault data (Fig. 9) shows that faults of all kinds are widespread in the study area. Most mapped fault traces are several tens of kilometers long, making them capable of generating $M=6+$ earthquakes (e.g., Leonard, 2010). Some from each fault type are much longer and potentially able to generate $M=7$ events.

Of the $\sim 250$ faults in the CCAF-DB, a little under half ( $~$ 120) have slip rates at the time of revision of this paper. These slip rates range from near zero to $80 \mathrm{~mm} \mathrm{a}^{-1}$, with a maximum of $\sim 20 \mathrm{~mm} \mathrm{a}^{-1}$ for onshore, continental faults (the Motagua fault). The median slip rate is $\sim 1 \mathrm{mma}^{-1}$, slightly higher than the median of $0.6 \mathrm{~mm} \mathrm{a}^{-1}$ for continental and intraplate faults in the current GEM Global Active Faults Database (Styron and Pagani, 2019).

\subsection{Distribution of deformation}

The patterns of deformation in Central America and the Caribbean region are largely the result of the interaction of the Caribbean plate with the adjacent North American, Cocos and South American plates; very little internal deformation of the Caribbean plate or deformation due to nonplate-tectonic processes such as gravitational collapse seem to be present. The width of the deforming zones around the Caribbean margin is variable and ostensibly linked to lithospheric composition: where the plate boundary type is between the ocean and ocean crust, strain is commonly localized to one or two faults, but where continental or transitional crust is involved, strain may be spread out over zones several hundred kilometers wide. This is consistent with observations elsewhere on Earth and is likely linked to the contrasting strength characteristic of the two types of lithosphere; oceanic plates are stronger and more homogeneous, while continental crust is weaker and may contain many preexisting planes of particular weakness due to rock layering or previous deformation events. This crustal heterogeneity may aid in distributing deformation over broad fault zones.

Many of the zones of complicated deformation are at stepovers in the major strike-slip fault systems, the northern Caribbean-North American plate boundary and the Central American forearc-bounding fault zone. An interesting aspect of the northern Caribbean-North American plate boundary through the Greater Antilles is that restraining bends in the sinistral plate boundary are mostly localized to the islands (particularly Hispaniola and Jamaica), while the undersea segments of the plate boundary are relatively straight. It is possible that it is mechanically favorable to localize the necessarily more complex and distributed faulting that occurs at stepovers in the weaker continental crust making up the islands.

\subsection{Faulting, seismic risk and uncertainty}

The majority of the region's $\sim 100$ million inhabitants live with substantial seismic hazard, and $\sim 80$ million people live within $50 \mathrm{~km}$ of the fault traces presented here; most of the population outside of this distance is in western Cuba or the southern Dominican Republic (including the Santo Domingo metro area). The former region is relatively safe, but the latter overlies the Los Muertos thrust though the trace is $>50 \mathrm{~km}$ south. The probabilistic seismic hazard and risk assessment done through the CCARA project quantitatively assesses the hazard and risk in the study area (e.g., Calderon and Silva, 2019), in part through modeling of faults presented here. 
Though we have coverage of the entire study region, much of the mapping should be considered provisional, and several areas are in need of additional, focused neotectonic mapping and studies of slip rates and paleoseismic history. The uncertainty in the slip rates and fault geometries for known faults in the area translate directly to greater variance in the PSHA results. The possibility for additional faults that are currently unknown is also quite high and represents potential seismic fault sources that are unaccounted for in existing fault source datasets and hazard models. The following areas are, from the perspective of seismic risk, the sites where focused geologic study would do most to increase the accuracy and decrease the epistemic uncertainty in the hazard models.

The faults surrounding Guatemala City (the Mixco and Guatemala City faults), San Pedro Sula in Honduras (the Sula graben) and San José in Costa Rica are all areas of active faulting in urbanized areas with very little local information on the geometries and slip rates of the faults. While the broad tectonic configuration of the Guatemala City and Sula grabens is relatively well understood, central Costa Rica is less so; it is densely vegetated, incompletely mapped and at a transition from transitional tension in the northwest to transpression in the southeast along the arc-parallel fault zone. Similarly, understanding more accurately where strain is being accommodated in Hispaniola, particularly whether strain is transferred south from the Oriente fault in the north through contractional faults along the island's western coast (as interpreted here) or through the San Juan valley in the center of the island, could be of both geological interest and hazard interest, as it shifts faulting farther from Port-auPrince and towards Santo Domingo. Similarly, though strain rates are likely 1-2 orders of magnitude lower than in these areas, a better understanding of the kinematics, slip rates and paleoseismic history of the great northern Puerto Rico fault zone would greatly improve our knowledge of the seismic hazard of the San Juan area.

\section{Conclusions}

The Caribbean and Central American region shows rapid deformation along the densely populated periphery of the Caribbean plate. A dataset of $\sim 250$ active fault traces, with geometric, kinematic and seismic hazard attributes, is presented here to characterize regional deformation and to serve as seismic hazard.

Central American deformation is caused by the interaction between the North American, Caribbean and Cocos plates. Regional deformation in northern Central America is transpressional, with reverse faults in the Chiapas fold and thrust belt and sinistral faults in southeastern Chiapas. South of Chiapas, the E-striking, sinistral Motagua-Polochic fault system forms the continental, western segment of the Caribbean-North American plate boundary. South of the Motagua-Polochic fault system, distributed normal faulting is present through the highlands of Guatemala, Honduras and El Salvador, with dextral faulting along the Central American volcanic arc associated with oblique subduction of the Cocos plate and northwestward translation of the Central American forearc. Southern Central America also shows transpressional deformation, with distributed reverse and strike-slip faulting in Costa Rica and reverse and sinistral faulting in Panama.

Faulting along the northern and eastern margins of the Caribbean plate results from the eastward translation of the Caribbean plate relative to the North and South American plates. The Greater Antilles lie along the east-striking, sinistral plate boundary between the Caribbean and North American plates. This boundary contains restraining bends that cut through Jamaica and Hispaniola, which have a mix of reverse and sinistral faults. The northeastern Caribbean plate contains sinistral and reverse faults near the Puerto Rico trench and normal faults in the upper plate. The Lesser Antilles islands lie on or near the volcanic arc created by subduction of Americas lithosphere underneath the Caribbean plate. Here, reverse faulting seems to be isolated at or near the megathrust, while dextral and normal faults are found near the arc, likely accommodating the extension and translation of forearc slivers in this region of variably oblique plate convergence.

Though a formal, quantitative seismic hazard and risk analysis is forthcoming, the distribution of faults and the available slip rate information suggest that the highest seismic risk is found in the large cities close to the Caribbean plate margins. The slip rates and seismic behavior of the proximal shallow faults in Central America have much greater uncertainty than in the Greater Antilles; neotectonic and paleoseismologic investigations of faults around Guatemala City (Guatemala), San Pedro Sula (Honduras) and San José (Costa Rica) would have a large impact in increasing the accuracy and reducing the epistemic uncertainty in seismic hazard and risk assessments of the areas.

The GEM CCAF-DB is a vector GIS database and provided in a range of purposes for different computing environments. The database is open source with a Creative Commons Attribution License (CC-BY 4.0). The database is meant to be incrementally updated as information becomes available, with changes and releases managed through the git version control system.

Data availability. The CCAF-DB (Styron et al., 2018) is publicly available at: https://github.com/GEMScienceTools/central_ am_carib_faults (last access: 23 March 2020).

Author contributions. RS performed background research, mapped the faults, constructed the database and wrote the paper. JG performed background research and provided assistance for other tasks. MP supervised the project. 
Competing interests. The authors declare that they have no conflict of interest.

Acknowledgements. We thank Paul Mann, Julian GarcíaMayordomo and the anonymous reviewer for constructive comments on this paper and the editorial staff, including Handling Editor Jean-Phillipe Malet, for their work. We also thank Sarah Nagorsen, John Weber and Jeff Lee for comments on a previous draft of this paper.

Financial support. This research has been supported by the US Agency for International Development (USAID; grant no. AIDOFDA-G-16-00149).

Review statement. This paper was edited by Heidi Kreibich and reviewed by Paul Mann, Julian Garcia-Mayordomo, and one anonymous referee.

\section{References}

Abbott, L. D., Silver, E. A., and Galewsky, J.: Structural evolution of a modern arc-continent collision in Papua New Guinea, Tectonics, 13, 1007-1034, https://doi.org/10.1029/94TC01623, 1994.

Ader, T., Avouac, J.-P., Liu-Zeng, J., Lyon-Caen, H., Bollinger, L., Galetzka, J., Genrich, J., Thomas, M., Chanard, K., Sapkota, S. N., Rajaure, S., Shrestha, P., Ding, L., and Flouzat, M.: Convergence rate across the Nepal Himalaya and interseismic coupling on the Main Himalayan Thrust: Implications for seismic hazard, J. Geophys. Res.-Solid, 117, B04403, https://doi.org/10.1029/2011JB009071, 2012.

Aki, K. and Richards, P. G.: Quantitative Seismology: Theory and Methods, W. H. Freeman, google-Books-ID: iYEwQQAACAAJ, 1980.

Alvarado, A., Audemard, F., Benavente Escobar, C., Santibanez Boric, I., Cembrano Perasso, J., Costa, C., Delgado Madera, G. F., García-Pelaez, J. A., Masquelin, E., Minaya, E., López, M. C., Paolini, M., Perez, I., Grupo de Neotectónica de SEGEMAR, and Styron, R.: the South American Risk Assessment Active Fault Database, https://doi.org/10.13117/SARAACTIVE-FAULTS, 2017.

Alvarado, D., DeMets, C., Tikoff, B., Hernandez, D., Wawrzyniec, T. F., Pullinger, C., Mattioli, G., Turner, H. L., Rodriguez, M., and Correa-Mora, F.: Forearc motion and deformation between El Salvador and Nicaragua: GPS, seismic, structural, and paleomagnetic observations, Lithosphere, 3, 3-21, https://doi.org/10.1130/L108.1, 2011.

Authemayou, C., Brocard, G., Teyssier, C., Simon-Labric, T., Guttiérrez, A., Chiquín, E. N., and Morán, S.: The CaribbeanNorth America-Cocos Triple Junction and the dynamics of the Polochic-Motagua fault systems: Pull-up and zipper models, Tectonics, 30, TC3010, https://doi.org/10.1029/2010TC002814, 2011.

Authemayou, C., Brocard, G., Teyssier, C., Suski, B., Cosenza, B., Morán-Ical, S., González-Véliz, C. W., Aguilar-Hengstenberg,
M. A., and Holliger, K.: Quaternary seismo-tectonic activity of the Polochic Fault, Guatemala, J. Geophys. Res.-Solid, 117, B07403, https://doi.org/10.1029/2012JB009444, 2012.

Barboza, G., Fernandez, J. A., Barrientos, J., and Bottazzi, G.: Costa Rica: petroleum geology of the Caribbean margin, Leading Edge, 16, 1787-1794, 1997.

Benford, B., DeMets, C., and Calais, E.: GPS estimates of microplate motions, northern Caribbean: evidence for a Hispaniola microplate and implications for earthquake hazard, Geophys. J. Int., 191, 481-490, https://doi.org/10.1111/j.1365246X.2012.05662.x, 2012a.

Benford, B., DeMets, C., Tikoff, B., Williams, P., Brown, L., and Wiggins-Grandison, M.: Seismic hazard along the southern boundary of the Gônave microplate: block modelling of GPS velocities from Jamaica and nearby islands, northern Caribbean, Geophys. J. Int., 190, 59-74, https://doi.org/10.1111/j.1365246X.2012.05493.x, 2012b.

Benford, B., Tikoff, B., and DeMets, C.: Interaction of reactivated faults within a restraining bend: Neotectonic deformation of southwest Jamaica, Lithosphere, 7, 21-39, https://doi.org/10.1130/L347.1, 2015.

Bennett, R. A., Spinler, J. C., Compton, K., Rockwell, T. K., and Gath, E.: Global Positioning System Constraints on Active Crustal Deformation in Central Panamá, Seismol. Res. Lett., 85, 278-283, https://doi.org/10.1785/0220130177, 2014.

Borrero, J. C., Kalligeris, N., Lynett, P. J., Fritz, H. M., Newman, A. V., and Convers, J. A.: Observations and Modeling of the August 27, 2012 Earthquake and Tsunami affecting El Salvador and Nicaragua, Pure Appl. Geophys., 171, 3421-3435, https://doi.org/10.1007/s00024-014-0782-2, 2014.

Boyer, S. E. and Elliott, D.: Thrust systems, AAPG Bulletin, 66, 1196-1230, https://doi.org/10.1306/03B5A77D-16D111D7-8645000102C1865D, 1982.

Brown, R. D., Ward, P. L., and Plafker, G.: Geologic and seismologic aspects of the Managua, Nicaragua, earthquakes of December 23, 1972, USGS Numbered Series 838, US Govt. Print. Off., available at: http://pubs.er.usgs.gov/publication/pp838 (last access: 23 March 2020), 1973.

Buck, W. R.: Flexural rotation of normal faults, Tectonics, 7, 959973, https://doi.org/10.1029/TC007i005p00959, 1988.

Bucknam, R. C., Plafker, G., and Sharp, R. V.: Fault movement (afterslip) following the Guatemala earthquake of February 4, 1976, Geology, 6, 170-173, https://doi.org/10.1130/00917613(1978)6<170:FMAFTG>2.0.CO;2, 1978.

Burkart, B. and Self, S.: Extension and rotation of crustal blocks in northern Central America and effect on the volcanic arc, Geology, 13, 22-26, https://doi.org/10.1130/00917613(1985)13<22:EAROCB>2.0.CO;2, 1985.

Calais, E. and de Lepinay, B. M.: From transtension to transpression along the northern Caribbean plate boundary off Cuba: implications for the Recent motion of the Caribbean plate, Tectonophysics, 186, 329-350, https://doi.org/10.1016/00401951(91)90367-2, 1991.

Calais, E., Béthoux, N., and de Lépinay, B. M.: From transcurrent faulting to frontal subduction: A seismotectonic study of the Northern Caribbean Plate Boundary from Cuba to Puerto Rico, Tectonics, 11, 114-123, https://doi.org/10.1029/91TC02364, 1992. 
Calais, E., Freed, A., Mattioli, G., Amelung, F., Jónsson, S., Jansma, P., Hong, S.-H., Dixon, T., Prépetit, C., and Momplaisir, R.: Transpressional rupture of an unmapped fault during the 2010 Haiti earthquake, Nat. Geosci., 3, 794-799, https://doi.org/10.1038/ngeo992, 2010.

Calderon, A. and Silva, V.: Probabilistic seismic vulnerability and loss assessment of the residential building stock in Costa Rica, Bull. Earthq. Eng., 17, 1257-1284, https://doi.org/10.1007/s10518-018-0499-1, 2019.

Camacho, E.: Sismotectónica del extremo norte de la zona de fractura de Panamá, Tecnoniencia, 5, 139-151, 2003.

Canora, C., Martínez-Díaz, J. J., Villamor, P., Berryman, K., Álvarez Gómez, J. A., Pullinger, C., and Capote, R.: Geological and Seismological Analysis of the 13 February $2001 \mathrm{Mw}$ 6.6 El Salvador Earthquake: Evidence for Surface Rupture and Implications for Seismic Hazard, Bull. Seismol. Soc. Am., 100, 2873 2890, https://doi.org/10.1785/0120090377, 2010.

Canora, C., Villamor, P., Martínez-Díaz, J. J., Berryman, K. R., Álvarez Gómez, J. A., Capote, R., and Hernández, W.: Paleoseismic analysis of the San Vicente segment of the El Salvador Fault Zone, El Salvador, Central America, Geol. Acta, 10, 103-123, 2012.

Carr, M. J.: Underthrusting and Quaternary faulting in northern Central America, GSA Bulletin, $\quad 87, \quad 825-829, \quad$ https://doi.org/10.1130/00167606(1976)87<825:UAQFIN>2.0.CO;2, 1976.

Carvajal-Arenas, L. C. and Mann, P.: Western Caribbean intraplate deformation: Defining a continuous and active microplate boundary along the San Andres rift and Hess Escarpment fault zone, Colombian Caribbean Sea, AAPG Bull., 102, 1523-1563, https://doi.org/10.1306/12081717221, 2018.

Chaytor, J. D. and ten Brink, U. S.: Extension in Mona Passage, Northeast Caribbean, Tectonophysics, 493, 74-92, https://doi.org/10.1016/j.tecto.2010.07.002, 2010.

Coates, A. G., Collins, L. S., Aubry, M.-P., and Berggren, W. A.: The Geology of the Darien, Panama, and the late Miocene-Pliocene collision of the Panama arc with northwestern South America, GSA Bulletin, 116, 1327-1344, https://doi.org/10.1130/B25275.1, 2004.

Corti, G., Carminati, E., Mazzarini, F., and Garcia, M. O.: Active strike-slip faulting in El Salvador, Central America, Geology, 33, 989-992, https://doi.org/10.1130/G21992.1, 2005.

Cowan, H., Prentice, C., Pantosti, D., d. Martini, P., Strauch, W., and Participants, W.: Late Holocene Earthquakes on the Aeropuerto Fault, Managua, Nicaragua, Bull. Seismol. Soc. Am., 92, 16941707, https://doi.org/10.1785/0120010100, 2002.

Cox, R. T., Lumsden, D. N., Gough, K., Lloyd, R., and Talnagi, J.: Investigation of late Quaternary fault block uplift along the Motagua/Swan Islands fault system: Implications for seismic/tsunami hazard for the Bay of Honduras, Tectonophysics, 457, 30-41, https://doi.org/10.1016/j.tecto.2008.05.014, 2008.

DeMets, C.: A new estimate for present-day Cocos-Caribbean Plate motion: Implications for slip along the Central American Volcanic Arc, Geophys. Res. Lett., 28, 4043-4046, https://doi.org/10.1029/2001GL013518, 2001.

DeMets, C. and Wiggins-Grandison, M.: Deformation of Jamaica and motion of the Gonâve microplate from GPS and seismic data, Geophys. J. Int., 168, 362-378, https://doi.org/10.1111/j.1365246X.2006.03236.x, 2007.
DeMets, C., Gordon, R. G., and Argus, D. F.: Geologically current plate motions, Geophys.J. Int., 181, 1-80, https://doi.org/10.1111/j.1365-246X.2009.04491.x, 2010.

Dolan, J. F., Mullins, H. T., and Wald, D. J.: Active tectonics of the north-central Caribbean: Oblique collision, strain partitioning, and opposing subducted slabs, in: Special Paper 326: Active Strike-Slip and Collisional Tectonics of the Northern Caribbean Plate Boundary Zone, vol. 326, Geological Society of America, Boulder, Colorado, USA, 1-61, https://doi.org/10.1130/0-81372326-4.1, 1998.

Ekström, G., Nettles, M., and Dziewoński, A. M.: The global CMT project 2004-2010: Centroid-moment tensors for 13,017 earthquakes, Phys. Earth Planet. Inter., 200-201, 1-9, https://doi.org/10.1016/j.pepi.2012.04.002, 2012.

Ellis, A., DeMets, C., McCaffrey, R., Briole, P., Cosenza Muralles, B., Flores, O., Guzmán-Speziale, M., Hernández, D., Kostoglodov, V., LaFemina, P., Lord, N., Lasserre, C., LyonCaen, H., Rodriguez Maradiaga, M., Molina, E., Rivera, J., Rogers, R., Staller, A., and Tikoff, B.: GPS constraints on deformation in northern Central America from 1999 to 2017, Part 2: Block rotations and fault slip rates, fault locking and distributed deformation, Geophys. J. Int., 218, 729-754, https://doi.org/10.1093/gji/ggz173, 2019.

Farr, T. G., Rosen, P. A., Caro, E., Crippen, R., Duren, R., Hensley, S., Kobrick, M., Paller, M., Rodriguez, E., Roth, L., Seal, D., Shaffer, S., Shimada, J., Umland, J., Werner, M., Oskin, M., Burbank, D., and Alsdorf, D.: The Shuttle Radar Topography Mission, Rev. Geophys., 45, RG2004, https://doi.org/10.1029/2005RG000183, 2007.

Feuillet, N., Tapponnier, P., Manighetti, I., Villemant, B., and King, G. C. P.: Differential uplift and tilt of Pleistocene reef platforms and Quaternary slip rate on the Morne-Piton normal fault (Guadeloupe, French West Indies), J. Geophys. Res.-Solid, 109, B02404, https://doi.org/10.1029/2003JB002496, 2004.

Feuillet, N., Beauducel, F., and Tapponnier, P.: Tectonic context of moderate to large historical earthquakes in the Lesser Antilles and mechanical coupling with volcanoes, J. Geophys. Res.-Solid, 116, B10308, https://doi.org/10.1029/2011JB008443, 2011.

Franco, A., Lasserre, C., Lyon-Caen, H., Kostoglodov, V., Molina, E., Guzman-Speziale, M., Monterosso, D., Robles, V., Figueroa, C., Amaya, W., Barrier, E., Chiquin, L., Moran, S., Flores, O., Romero, J., Santiago, J. A., Manea, M., and Manea, V. C.: Fault kinematics in northern Central America and coupling along the subduction interface of the Cocos Plate, from GPS data in Chiapas (Mexico), Guatemala and El Salvador: Kinematics in northern Central America, Geophys. J. Int., 189, 1223-1236, https://doi.org/10.1111/j.1365-246X.2012.05390.x, 2012.

Freundt, A., Hartmann, A., Kutterolf, S., and Strauch, W.: Volcaniclastic stratigraphy of the Tiscapa maar crater walls (Managua, Nicaragua): implications for volcanic and seismic hazards and Holocene climate changes, Int. J. Earth Sci., 99, 1453-1470, https://doi.org/10.1007/s00531-009-0469-6, 2010.

Funk, J., Mann, P., McIntosh, K., and Stephens, J.: Cenozoic tectonics of the Nicaraguan depression, Nicaragua, and Median Trough, El Salvador, based on seismic-reflection profiling and remote-sensing data, Geol. Soc. Am. Bull., 121, 1491-1521, 2009.

García, J., Slejko, D., Alvarez, L., Peruzza, L., and Rebez, A.: Seismic Hazard Maps for Cuba and Surround- 
ing Areas, Bull. Seismol. Soc. Am., 93, 2563-2590, https://doi.org/10.1785/0120020144, 2003.

Gomez, S., Bird, D., and Mann, P.: Deep crustal structure and tectonic origin of the Tobago-Barbados ridge, Interpretation, 6, T471-T484, https://doi.org/10.1190/INT-2016-0176.1, 2018.

Gordon, M. B. and Muehlberger, W. R.: Rotation of the Chortís block causes dextral slip on the Guayape fault, Tectonics, 13, 858-872, https://doi.org/10.1029/94TC00923, 1994.

Gordon, M. B., Mann, P., Cáceres, D., and Flores, R.: Cenozoic tectonic history of the North America-Caribbean plate boundary zone in western Cuba, J. Geophys. Res.-Solid, 102, 1005510082, https://doi.org/10.1029/96JB03177, 1997.

Graham, S. E., DeMets, C., DeShon, H. R., Rogers, R., Maradiaga, M. R., Strauch, W., Wiese, K., and Hernandez, D.: GPS and seismic constraints on the $M=7.32009$ Swan Islands earthquake: implications for stress changes along the Motagua fault and other nearby faults, Geophys. J. Int., 190, 1625-1639, https://doi.org/10.1111/j.1365-246X.2012.05560.x, 2012.

Graham, S. E., Loveless, J. P., and Meade, B. J.: Global Plate Motions and Earthquake Cycle Effects, Geochem. Geophy. Geosy., 19, 2032-2048, https://doi.org/10.1029/2017GC007391, 2018.

Granja Bruña, J. L., ten Brink, U. S., Carbó-Gorosabel, A., Muñoz-Martín, A., and Gómez Ballesteros, M.: Morphotectonics of the central Muertos thrust belt and Muertos Trough (northeastern Caribbean), Mar. Geol., 263, 7-33, https://doi.org/10.1016/j.margeo.2009.03.010, 2009.

Grindlay, N. R., Abrams, L. J., Del Greco, L., and Mann, P.: Toward an integrated understanding of Holocene fault activity in western Puerto Rico: Constraints from high-resolution seismic and sidescan sonar data, in: Special Paper 385: Active Tectonics and Seismic Hazards of Puerto Rico, the Virgin Islands, and Offshore Areas, vol. 385, Geological Society of America, Boulder, Colorado, USA, 139-160, https://doi.org/10.1130/0-8137-2385X.139, 2005a.

Grindlay, N. R., Mann, P., Dolan, J. F., and van Gestel, J.-P.: Neotectonics and subsidence of the northern Puerto Rico-Virgin Islands margin in response to the oblique subduction of highstanding ridges, in: Special Paper 385: Active Tectonics and Seismic Hazards of Puerto Rico, the Virgin Islands, and Offshore Areas, vol. 385, Geological Society of America, Boulder, Colorado, USA, 31-60, https://doi.org/10.1130/0-8137-2385-X.31, 2005b.

Guzmán-Speziale, M.: Active seismic deformation in the grabens of northern Central America and its relationship to the relative motion of the North America-Caribbean plate boundary, Tectonophysics, 337, 39-51, https://doi.org/10.1016/S00401951(01)00110-X, 2001.

Guzmán-Speziale, M.: Beyond the Motagua and Polochic faults: Active strike-slip faulting along the Western North AmericaCaribbean plate boundary zone, Tectonophysics, 496, 17-27, https://doi.org/10.1016/j.tecto.2010.10.002, 2010.

Hayman, N. W., Grindlay, N. R., Perfit, M. R., Mann, P., Leroy, S., and de Lépinay, B. M.: Oceanic core complex development at the ultraslow spreading Mid-Cayman Spreading Center, Geochem. Geophy. Geosy., 12, Q0AG02, https://doi.org/10.1029/2010GC003240, 2011.

Hippolyte, J.-C., Mann, P., and Grindlay, N. R.: Geologic evidence for the prolongation of active normal faults of the Mona rift into northwestern Puerto Rico, in: Special Paper 385: Active Tectonics and Seismic Hazards of Puerto Rico, the Virgin Islands, and
Offshore Areas, vol. 385, Geological Society of America, Boulder, Colorado, USA, 161-171, https://doi.org/10.1130/0-81372385-X.161, 2005.

Jansma, P. E. and Mattioli, G. S.: GPS results from Puerto Rico and the Virgin Islands: Constraints on tectonic setting and rates of active faulting, in: Special Paper 385: Active Tectonics and Seismic Hazards of Puerto Rico, the Virgin Islands, and Offshore Areas, vol. 385, Geological Society of America, Boulder, Colorado, USA, 13-30, https://doi.org/10.1130/0-8137-2385-X.13, 2005.

Kanamori, H. and Kikuchi, M.: The 1992 Nicaragua earthquake: a slow tsunami earthquake associated with subducted sediments, Nature, 361, 714-716, https://doi.org/10.1038/361714a0, 1993.

Koehler, R. D., Mann, P., Prentice, C. S., Brown, L., Benford, B., and Wiggins-Grandison, M.: Enriquillo-Plantain Garden Fault Zone in Jamaica: Paleoseismology and Seismic Hazard, Bull. Seismol. Soc. America, 103, 971-983, https://doi.org/10.1785/0120120215, 2013.

Koulali, A., Tregoning, P., McClusky, S., Stanaway, R., Wallace, L., and Lister, G.: New Insights into the present-day kinematics of the central and western Papua New Guinea from GPS, Geophys. J. Int., 202, 993-1004, https://doi.org/10.1093/gji/ggv200, 2015.

Kreemer, C., Blewitt, G., and Klein, E. C.: A geodetic plate motion and Global Strain Rate Model, Geochem. Geophy. Geosy., 15, 3849-3889, https://doi.org/10.1002/2014GC005407, 2014.

Kula, D.: Neotectonics on the edge of the Cuban Fold and Thrust Belt, available at: http://scholarlyrepository.miami.edu/ oa_theses/498/ (last access: 23 March 2020), 2014.

LaFemina, P. C., Dixon, T. H., and Strauch, W.: Bookshelf faulting in Nicaragua, Geology, 30, 751-754, 2002.

LaFemina, P. C., Dixon, T. H., Govers, R., Norabuena, E., Turner, H., Saballos, A., Mattioli, G., Protti, M., and Strauch, W.: Fore-arc motion and Cocos Ridge collision in Central America, Geochem. Geophy. Geosy., 10, Q05S14, https://doi.org/10.1029/2008GC002181, 2009.

Lavé, J. and Avouac, J. P.: Active folding of fluvial terraces across the Siwaliks Hills, Himalayas of central Nepal, J. Geophys. Res.Solid, 105, 5735-5770, https://doi.org/10.1029/1999JB900292, 2000.

Leonard, M.: Earthquake Fault Scaling: Self-Consistent Relating of Rupture Length, Width, Average Displacement, and Moment Release, Bull. Seismol. Soc. Am., 100, 1971-1988, https://doi.org/10.1785/0120090189, 2010.

Leroy, S., Mauffret, A., Patriat, P., and Mercier de Lépinay, B.: An alternative interpretation of the Cayman trough evolution from a reidentification of magnetic anomalies, Geophys. J. Int., 141, 539-557, https://doi.org/10.1046/j.1365246x.2000.00059.x, 2000.

Leroy, S., Ellouz-Zimmermann, N., Corbeau, J., Rolandone, F., de Lépinay, B. M., Meyer, B., Momplaisir, R., Granja Bruña, J.-L., Battani, A., Baurion, C., Burov, E., Clouard, V., Deschamps, R., Gorini, C., Hamon, Y., Lafosse, M., Leonel, J., Le Pourhiet, L., Llanes Estrada, P., Loget, N., Lucazeau, F., Pillot, D., Poort, J., Tankoo, K. R., Cuevas, J.-L., Alcaide, J.F., Jean Poix, C., Muñoz-Martin, A., Mitton, S., Rodriguez, Y., Schmitz, J., Seeber, L., Carbo-Gorosabel, A., and Muñoz, S.: Segmentation and kinematics of the North America-Caribbean plate boundary offshore Hispaniola, Terra Nova, 27, 467-478, https://doi.org/10.1111/ter.12181, 2015. 
Liu, H. and Wang, G.: Relative Motion between St. Croix and the Puerto Rico-Northern Virgin Islands Block Derived from Continuous GPS Observations (1995-2014), Int. J. Geophys., 2015, 915753, https://doi.org/10.1155/2015/915753, 2015.

Lyon-Caen, H., Barrier, E., Lasserre, C., Franco, A., Arzu, I., Chiquin, L., Chiquin, M., Duquesnoy, T., Flores, O., Galicia, O., Luna, J., Molina, E., Porras, O., Requena, J., Robles, V., Romero, J., and Wolf, R.: Kinematics of the North American-CaribbeanCocos plates in Central America from new GPS measurements across the Polochic-Motagua fault system, Geophys. Res. Lett., 33, L19309, https://doi.org/10.1029/2006GL027694, 2006.

Mann, P. and Corrigan, J.: Model for late Neogene deformation in Panama, Geology, 18, 558-562, https://doi.org/10.1130/00917613(1990)018<0558:MFLNDI >2.3.CO;2, 1990.

Mann, P., Burke, K., and Matumoto, T.: Neotectonics of Hispaniola: plate motion, sedimentation, and seismicity at a restraining bend, Earth Planet. Sc. Lett., 70, 311-324, https://doi.org/10.1016/0012-821X(84)90016-5, 1984.

Mann, P., Prentice, C. S., Burr, G., Peña, L. R., and Taylor, F. W.: Tectonic geomorphology and paleoseismology of the Septentrional fault system, Dominican Republic, in: Special Paper 326: Active Strike-Slip and Collisional Tectonics of the Northern Caribbean Plate Boundary Zone, vol. 326, Geological Society of America, Boulder, Colorado, USA, 63-123, https://doi.org/10.1130/0-8137-2326-4.63, 1998.

Mann, P., Hippolyte, J.-C., Grindlay, N. R., and Abrams, L. .: Neotectonics of southern Puerto Rico and its offshore margin, in: Special Paper 385: Active Tectonics and Seismic Hazards of Puerto Rico, the Virgin Islands, and Offshore Areas, vol. 385, Geological Society of America, Boulder, Colorado, USA, 173214, https://doi.org/10.1130/0-8137-2385-X.173, 2005a.

Mann, P., Prentice, C. S., Hippolyte, J.-C., Grindlay, N. R., Abrams, L. J., and Laó-Dávila, D.: Reconnaissance study of Late Quaternary faulting along Cerro Goden fault zone, western Puerto Rico, in: Special Paper 385: Active Tectonics and Seismic Hazards of Puerto Rico, the Virgin Islands, and Offshore Areas, vol. 385, Geological Society of America, Boulder, Colorado, USA, 115137, https://doi.org/10.1130/0-8137-2385-X.115, 2005b.

Marshall, J. S., Fisher, D. M., and Gardner, T. W.: Central Costa Rica deformed belt: Kinematics of diffuse faulting across the western Panama block, Tectonics, 19, 468-492, https://doi.org/10.1029/1999TC001136, 2000.

Martínez-Díaz, J. J., Álvarez Gómez, J. A., Benito, B., and Hernández, D.: Triggering of destructive earthquakes in El Salvador, Geology, 32, 65-68, https://doi.org/10.1130/G20089.1, 2004.

Mauffret, A. and Leroy, S.: Neogene intraplate deformation of the Caribbean Plate at the Beata Ridge, in: Sedimentary Basins of the World, vol. 4 of Caribbean Basins, 627669, available at: http://www.sciencedirect.com/science/article/ pii/S1874599799800550 (last access: 23 March 2020), 1999.

McCaffrey, R. and Nabelek, J.: Role of oblique convergence in the active deformation of the Himalayas and southern Tibet plateau, Geology, 26, 691-694, 1998.

McKenzie, D.: Active Tectonics of the Mediterranean Region, Geophys. J. Int., 30, 109-185, https://doi.org/10.1111/j.1365246X.1972.tb02351.x, 1972.

Meneses-Rocha, J. J.: Tectonic evolution of the Ixtapa Graben, an example of a strike-slip basin of southeastern Mexico: Implications for regional petroleum systems, in: The west- ern Gulf of Mexico Basin: Tectonics, sedimentary basins, and petroleum systems, no. 75 in AAPG Memoir, 183-218, available at: http://www.geociencias.unam.mx/ rmolina/documents/ meneses-aapg_2001.pdf (last access: 23 March 2020), 2001.

Molina-Garza, R. S., Geissman, J. W., Wawrzyniec, T. F., Peña Alonso, T. A., Iriondo, A., Weber, B., and Aranda-Gómez, J.: Geology of the coastal Chiapas (Mexico) Miocene plutons and the Tonala shear zone: Syntectonic emplacement and rapid exhumation during sinistral transpression, Lithosphere, 7, 257274, https://doi.org/10.1130/L409.1, 2015.

Mondziel, S., Grindlay, N., Mann, P., Escalona, A., and Abrams, L.: Morphology, structure, and tectonic evolution of the Mona canyon (northern Mona passage) from multibeam bathymetry, side-scan sonar, and seismic reflection profiles, Tectonics, 29, TC2003, https://doi.org/10.1029/2008TC002441, 2010.

Montero, P. W., Lewis, J. C., Marshall, J. S., Kruse, S., and Wetmore, P.: Neotectonic faulting and forearc sliver motion along the Atirro-Río Sucio fault system, Costa Rica, Central America, Geol. Soc. Am. Bull., 125, 857-876, 2013.

Piety, L. A., Redwine, J. R., Derouin, S. A., Prentice, C. S., Kelson, K. I., Klinger, R. E., and Mahan, S.: Holocene Surface Ruptures on the Salinas Fault and Southeastern Great Southern Puerto Rico Fault Zone, South Coastal Plain of Puerto RicoHolocene Surface Ruptures on the Salinas Fault and Southeastern GSPRFZ, South Coastal Plain of Puerto Rico, Bull. Seismol. Soc. Am., 108, 619-638, https://doi.org/10.1785/0120170182, 2018.

Plafker, G.: Tectonic Aspects of the Guatemala Earthquake of 4 February 1976, Science, 193, 1201-1208, https://doi.org/10.1126/science.193.4259.1201, 1976.

Prentice, C. S. and Mann, P.: Paleoseismic study of the South Lajas fault: First documentation of an onshore Holocene fault in Puerto Rico, in: Special Paper 385: Active Tectonics and Seismic Hazards of Puerto Rico, the Virgin Islands, and Offshore Areas, vol. 385, Geological Society of America, Boulder, Colorado, USA, 215-222, https://doi.org/10.1130/0-8137-2385X.215, 2005.

Prentice, C. S., Mann, P., Peña, L. R., and Burr, G.: Slip rate and earthquake recurrence along the central Septentrional fault, North American-Caribbean plate boundary, Dominican Republic, J. Geophys. Res.-Solid, 108, 2149, https://doi.org/10.1029/2001JB000442, 2003.

Pubellier, M., Mauffret, A., Leroy, S., Vila, J. M., and Amilcar, H.: Plate boundary readjustment in oblique convergence: Example of the Neogene of Hispaniola, Greater Antilles, Tectonics, 19, 630-648, https://doi.org/10.1029/2000TC900007, 2000.

Rockwell, T. K., Gath, E., Gonzalez, T., Madden, C., Verdugo, D., Lippincott, C., Dawson, T., Owen, L. A., Fuchs, M., Cadena, A., Williams, P., Weldon, E., and Franceschi, P.: Neotectonics and Paleoseismology of the Limon and Pedro Miguel Faults in Panama: Earthquake Hazard to the Panama Canal, Bull. Seismol. Soc. Am., 100, 3097-3129, https://doi.org/10.1785/0120090342, 2010a.

Rockwell, T. K., Bennett, R. A., Gath, E., and Franceschi, P.: Unhinging an indenter: A new tectonic model for the internal deformation of Panama, Tectonics, 29, TC4027, https://doi.org/10.1029/2009TC002571, 2010b.

Rodriguez, J., Havskov, J., Sørensen, M. B., and Santos, L. F.: Seismotectonics of south-west Dominican Republic using recent 
data, J. Seismol., 22, 883-896, https://doi.org/10.1007/s10950018-9738-9, 2018.

Rodriguez, M., DeMets, C., Rogers, R., Tenorio, C., and Hernandez, D.: A GPS and modelling study of deformation in northern Central America, Geophys. J. Int., 178, 1733-1754, https://doi.org/10.1111/j.1365-246X.2009.04251.x, 2009.

Rogers, R. D. and Mann, P.: Transtensional deformation of the western Caribbean-North America plate boundary zone, in: Geologic and Tectonic Development of the Caribbean Plate Boundary in Northern Central America, vol. 428 of Geological Society of America Special Papers, Geological Society of America, Boulder, Colorado, USA, 37-64, https://doi.org/10.1130/2007.2428(03), 2007.

Roig-Silva, C. M., Asencio, E., and Joyce, J.: The Northwest Trending North Boqueron Bay-Punta Montalva Fault Zone; A Through Going Active Fault System in Southwestern Puerto Rico, Seismol. Res. Lett., 84, 538-550, https://doi.org/10.1785/0220120115, 2013.

Rosen, P. A., Hensley, S., Joughin, I. R., Li, F. K., Madsen, S. N., Rodriguez, E., and Goldstein, R. M.: Synthetic aperture radar interferometry, Proc. IEEE, 88, 333-382, 2000.

Rosencrantz, E. and Mann, P.: SeaMARC II mapping of transform faults in the Cayman Trough, Caribbean Sea, Geology, 19, 690-693, https://doi.org/10.1130/00917613(1991)019<0690:SIMOTF>2.3.CO;2, 1991.

Ryan, W. B. F., Carbotte, S. M., Coplan, J. O., O’Hara, S., Melkonian, A., Arko, R., Weissel, R. A., Ferrini, V., Goodwillie, A., Nitsche, F., Bonczkowski, J., and Zemsky, R.: Global MultiResolution Topography synthesis, Geochem. Geophy. Geosy., 10, Q03014, https://doi.org/10.1029/2008GC002332, 2009.

Saint Fleur, N., Feuillet, N., Grandin, R., Jacques, E., WeilAccardo, J., and Klinger, Y.: Seismotectonics of southern Haiti: A new faulting model for the 12 January 2010 M7.0 earthquake, Geophys. Res. Lett., 42, 10273-10281, https://doi.org/10.1002/2015GL065505, 2015.

Schwartz, D. P., Cluff, L. S., and Donnelly, T. W.: Quaternary faulting along the Caribbean-North American plate boundary in Central America, Tectonophysics, 52, 431-445, https://doi.org/10.1016/0040-1951(79)90258-0, 1979.

Sitchler, J. C., Fisher, D. M., Gardner, T. W., and Protti, M.: Constraints on inner forearc deformation from balanced cross sections, Fila Costña thrust belt, Costa Rica, Tectonics, 26, TC6012, https://doi.org/10.1029/2006TC001949, 2007.

Sorichetta, A., Hornby, G. M., Stevens, F. R., Gaughan, A. E., Linard, C., and Tatem, A. J.: High-resolution gridded population datasets for Latin America and the Caribbean in 2010, 2015, and 2020, Scient. Data, 2, 1-12, https://doi.org/10.1038/sdata.2015.45, 2015.

Staller, A., Martínez-Díaz, J. J., Benito, B., Alonso-Henar, J., Hernández, D., Hernández-Rey, R., and Díaz, M.: Presentday crustal deformation along the El Salvador Fault Zone from ZFESNet GPS network, Tectonophysics, 670, 66-81, https://doi.org/10.1016/j.tecto.2015.12.017, 2016.

Styron, R. H.: Kinematics of the Western Margin of Nicaragua from GPS Geodesy, MS thesis, University of Arkansas, Fayetteville, 2008.

Styron, R. H. and Pagani, M.: The GEM Global Active Faults Database (GAF-DB), Earthquake Spectra, in review, 2019.
Styron, R. H., García-Pelaez, J., and Pagani, M.: GEM Central America and Caribbean Active Faults Database, https://doi.org/10.13117/CENTRAL-AMERICACARIBBEAN-ACTIVE-FAULTS, 2018.

Styron, R. H., Taylor, M. H., and Murphy, M. A.: Oblique convergence, arc-parallel extension, and the role of strike-slip faulting in the High Himalaya, Geosphere, 7, 582-596, 2011.

Suárez, G., Pardo, M., Domínguez, J., Ponce, L., Montero, W., Boschini, I., and Rojas, W.: The Limón, Costa Rica earthquake of April 22, 1991: Back arc thrusting and collisional tectonics in a subduction environment, Tectonics, 14, 518-530, https://doi.org/10.1029/94TC02546, 1995.

Suárez, G., Muñoz, A., Farraz, I. A., Talavera, E., Tenorio, V., Novelo-Casanova, D. A., and Sánchez, A.: The 10 April 2014 Nicaraguan Crustal Earthquake: Evidence of Complex Deformation of the Central American Volcanic Arc, Pure Appl. Geophys., 173, 3305-3315, https://doi.org/10.1007/s00024-0151201-z, 2016.

Symithe, S., Calais, E., de Chabalier, J. B., Robertson, R., and Higgins, M.: Current block motions and strain accumulation on active faults in the Caribbean, J. Geophys. Res.-Solid, 120, 37483774, https://doi.org/10.1002/2014JB011779, 2015.

ten Brink, U. S. and López-Venegas, A. M.: Plate interaction in the NE Caribbean subduction zone from continuous GPS observations, Geophys. Res. Lett., 39, L10304, https://doi.org/10.1029/2012GL051485, 2012.

ten Brink, U. S., Danforth, W., Polloni, C., Andrews, B., Llanes, P., Smith, S., Parker, E., and Uozumi, T.: New seafloor map of the Puerto Rico trench helps assess earthquake and tsunami hazards, Eos Trans. Am. Geophys. Union, 85, 349-354, https://doi.org/10.1029/2004EO370001, 2004.

Turner, H. L., LaFemina, P., Saballos, A., Mattioli, G. S., Jansma, P. E., and Dixon, T.: Kinematics of the Nicaraguan forearc from GPS geodesy, Geophys. Res. Lett., 34, L02302, https://doi.org/10.1029/2006GL027586, 2007.

Veloza, G., Styron, R., Taylor, M., and Mora, A.: Open-source archive of active faults for northwest South America, GSA Today, 22, 4-10, https://doi.org/10.1130/GSAT-G156A.1, 2012.

Villegas, G. C., Mendoza, C., and Ferrari, L.: Mexico Quaternary Fault Database, Terra Digitalis, 1, 1-9, https://doi.org/10.22201/igg.terradigitalis.2017.1.3.50, 2017.

Wallace, L. M., Stevens, C., Silver, E., McCaffrey, R., Loratung, W., Hasiata, S., Stanaway, R., Curley, R., Rosa, R., and Taugaloidi, J.: GPS and seismological constraints on active tectonics and arc-continent collision in Papua New Guinea: Implications for mechanics of microplate rotations in a plate boundary zone, J. Geophys. Res.-Solid, 109, B05404, https://doi.org/10.1029/2003JB002481, 2004.

Wang, J., Mann, P., and Stewart, R. R.: Late Holocene Structural Style and Seismicity of Highly Transpressional Faults in Southern Haiti, Tectonics, 37, 3834-3852, https://doi.org/10.1029/2017TC004920, 2018.

Wesnousky, S. G.: Displacement and Geometrical Characteristics of Earthquake Surface Ruptures: Issues and Implications for Seismic-Hazard Analysis and the Process of Earthquake Rupture, Bull. Seismol. Soc. Am., 98, 1609-1632, https://doi.org/10.1785/0120070111, 2008. 
Wessel, P. and Smith, W. H. F.: A global, self-consistent, hierarchical, high-resolution shoreline database, J. Geophys. Res.-Solid, 101, 8741-8743, https://doi.org/10.1029/96JB00104, 1996.

White, R. A. and Harlow, D. H.: Destructive upper-crustal earthquakes of Central America since 1900, Bull. Seismol. Soc. Am., 83, 1115-1142, 1993
Witt, C., Rangin, C., Andreani, L., Olaez, N., and Martinez, J.: The transpressive left-lateral Sierra Madre de Chiapas and its buried front in the Tabasco plain (southern Mexico), J. Geol. Soc., 169, 143-155, https://doi.org/10.1144/0016-76492011-024, 2012 